\title{
OLD CUPS DIE HARD: THE APPROPRIATION OF ATHENIAN POTTERY IN THE IBERIAN PENINSULA
}

\author{
DIANA RODRÍGUEZ PÉREZ \\ University of Oxford ${ }^{*}$
}

\begin{abstract}
The Iberian archaeological record is particularly rich in asynchronous assemblages including Athenian pots that predate the other items by a couple of decades or even a few centuries. Recent scholarship on keimèlia or 'curated' objects, in modern parlance, has shown the potential of such objects to investigate questions of identity, agency and history making among the receiving communities, but also to shed light on the role of Athenian pottery among them. This article analyses such phenomenon within the Iberian Peninsula, focusing on drinking cups, both black-gloss with inset lip (Cástulo cups) and red-figure type B cups. Using case studies from necropoleis and settlements of the southeast and east of the Peninsula, the article explores the reasons and meaning of this consumption practice. It is argued that the occurrence of 'aged' vases in Iberian tombs and their extraordinary survival in some settlements is the result of a conscious and motivated choice that is indicative of the existence of mechanisms of social distinction based on a diacritic use of material culture. It is further argued that different motivations might lay behind their delayed deposition: when the chronological gap between production and disposal dates is small - one or two human generations -, curated Athenian vases worked similarly to non-curated ones, being emblematic of economic success, social affiliations and political rank. But when the interval is long enough, Athenian pots become symbols of ancestry and elite status, possibly acquiring the same legitimizing role earlier bestowed upon Orientalizing artefacts.
\end{abstract}

Keywords: Athenian pottery, Iberian Peninsula, heirlooms, cups, bell-krater

Achievements in the political, social, and economic realms may make a Big Man, but only with material symbols - such as heirlooms - will chiefs and chiefly lineages be recognized as legitimate over many generations. ${ }^{1}$

\section{Introduction}

The use of the past, in particular, in the funerary realm, is a common device employed in times of uncertainty, social turmoil and change. The desire to create historical continuity between non-contiguous points in time, the philosophical question of how identities can

\footnotetext{
* diana.rodriguezperez@wolfson.ox.ac.uk. This article is part of a larger research on the consumption of Athenian pottery in the Iberian Peninsula carried out at Wolfson College, Oxford, thanks to the financial support of a Junior Research Fellowship Mougins Museum in Classical Art and Material Culture (2016-2019). Part of the research was done in the John Miller Burnam Library of the Department of Classics of the University of Cincinnati during a Tytus summer residency in 2017, for which I am most grateful. The article has benefitted from the feedback of the following scholars (in alphabetical order): Paloma Cabrera, Adolfo Domínguez Monedero, Raimon Graells i Fabregat, Søren Handberg. Carmen Sánchez Fernández, Mark Stansbury O'Donnell, Ann Steiner and Vivi Saripanidi. I would like to thank the following people for granting me access to material, publications and/or photographs: Esperanza Manso Martín (MAN), Carmen Rueda Galán (UJA), Jorge García Cardiel (UAM), Enric Verdú Parra (MARQ), Arturo Oliver Foix (Diputación de Castellón), José Manuel Melchor Monserrat (Museo de Burriana), Amanda Reiterman (UCSC), Stéphane Verger (EPHE), Marta Santos Retolaza, Pere Castanyer Masoliver and Elisa Hernández Pastor (Ampurias) and Gabriel de Prados and Ferrán Codina (Ullastret). I would also like to thank Kathleen Lynch for her generous support during my stay in Cincinnati as well as Tom Carpenter, with whom I discussed some aspects of my research. Thomas Mannack, Peter Stewart and Carmen Sánchez have helped me in countless ways throughout these years. I would also like to thank $J H S$ ' anonymous reviewers for their pertinent and relevant suggestions, which have helped me improve the manuscript. All errors and shortcomings remain my responsibility.
}

${ }^{1}$ Lillios (1999) 237. 
indeed persist in the face of constant change and the use of material culture to remember or manipulate the past seems to be a Leitmotiv of human behaviour. ${ }^{2}$ The mental act performed to bridge the gap between non-contiguous points in history receives the name of 'mnemonic bridging' 3 and such an act can be identified in the archaeological record by the use of relics, memorabilia, heirlooms and other heavily entangled objects, which results in asynchronous assemblages, i.e. artefacts that predate the other items in their assemblage, objects exhibiting ancient repairs or even physiognomic 'hybrid' artefacts that seemingly conflate various cultural traditions. Tombs and sanctuaries are the two main contexts where acts of mnemonic bridging can be identified. ${ }^{4}$

The Iberian archaeological record is rich in such anomalous objects. Material culture was used in a rather pervasive way in various moments of the development of the Iberian culture in connection with processes of political and social legitimacy, such as the transition to the early Iberian period (seventh and sixth centuries) with the emergence of the aristocracy, the transition to the High Iberian period in the middle of the fifth century, or the consolidation of the aristocratic model based on the clientele and centred in the oppidum (fortified town) as defining entity in the fourth century BC..$^{5}$ The evocation of the past among the Iberians materializes in the persistence of the west Phoenician iconographic tradition of the Orientalizing period (seventh century BC) ${ }^{6}$ well into the fifth and fourth centuries BC. Relevant examples include the popularity of iconographic motifs such as griffins, often in combat scenes with a hero/god, and trees of life in Iberian material culture; ${ }^{7}$ the occurrence of Orientalizing artefacts in Iberian contexts, such as the Lady of Galera (Galera, Granada) ${ }^{8}$ or the thumiaterion of La Quéjola (San Pedro, Albacete); ${ }^{9}$ and of creative Orientalizing

2 Lillios (1999) 241; Zerubavel (2003) 39. For the use, creation and re-creation of the past among the Greeks, see Boardman (2002).

3 Zerubavel (2003) 39-46.

4 Sanctuaries accumulated all sorts of objects of different chronologies at any one time that were dedicated to the gods for different reasons. The dedication of metal armour and weapons in such contexts has received increasing attention in the last decades. For a comprehensive summary of modes of display and curation as well as of the socio-political dimension of the dedication of armour in sanctuaries, see Graells et al. (2017) 147-78 and Graells (2016).

5 On the development of the Iberian culture, see Gracia (2008), Sánchez and Gómez (2008) 21-126; Aranegui (2012) and Cruz et al. (2013). Also, Ruiz and Molinos (2015) for the region of the High Andalucia and their 1993 book with English translation in 1998, which is now outdated.

6 On the definition and application of the term 'Orientalizing' to the Iberian Peninsula, see Jiménez (2002) 1921. Also, Aubet (2005).

7 E.g. The early fourth-century larnax from tomb 76 of Galera, Madrid, Museo Arqueológico Nacional inv. no. 1979/70/GAL/T76/1A, Chapa (2004); the gryphomachy of the fifth-century sculptural group of Cerrillo Blanco (Porcuna, Jaén), Negueruela (1990); or the griffins which protect the hero in the early fourth-century sculptural group of the sanctuary of El Pajarillo (Huelma, Jaén), Molinos et al. (1998).

8 Madrid, Museo Arqueológico Nacional inv. no. 33438, Olmos (2004) and Almagro-Gorbea (2009b).

${ }^{9}$ Albacete, Museo Arqueológico Provincial inv. no. 8366. 
'revivals', like the polychrome vessels of tombs 155 of Baza (Baza, Granada)10 (fig. 1) and 34 of Galera (Galera, Granada), ${ }^{11}$ and hybrid productions like the fifth-century krater of Atalayuelas (Fuerte del Rey, Jaén), 12 an extraordinary example of the resilience of the Orientalizing pictorial tradition on a local imitation of an Athenian column-krater (for a map of the sites mentioned in the text, see fig. 2).

The Phoenician colonization - first archaeological evidence of a Phoenician settlement in Gadir (Cádiz) date to $c a .800 \mathrm{BC}^{13}$ - had brought a wide range of typically oriental iconographies transmitted in various media, from textiles to ivory plaques. This Orientalizing visual culture is the local tradition in which the emerging Iberian communities of the south had been nurtured and is the reference framework at which they look early on in their process of identity and memory making. As with the Late Bronze Age in Greece, in the Iberian Peninsula the Orientalizing period was the time in which later generations sought to be grounded and to which they looked back with nostalgia. According to Ricardo Olmos, ${ }^{14}$ two reasons account for this choice: (1) the exotic and quasi magical character of the Mediterranean orientalising productions - gold, ivory, alabaster, perfumes, painted vases and textiles - that arrived in the Peninsula through long-distance trade and were possibly associated with ancestral legends and (2) the remoteness of a distant past directly linked with long-gone ancestors. The Orientalizing system would be later replaced by the Greek visual culture in a process that did not lack its tensions. The dialogue and, sometimes, actual clash between both traditions has been explored by Olmos throughout his oeuvre. ${ }^{15}$

Athenian pots, in turn, also have a pervasive presence in the Iberian archaeological record and went through interesting episodes of curation and 'treasurisation', being deposited decades and, on some occasions, centuries, after their estimated manufacture date. New research on the chronology of some classes of Athenian pots (e.g. the Cástulo cups, floruit 480-425 BC) evidences that quite often the Attic material from several remarkable Iberian tombs of the late fifth century and later can be understood as keimèlia (i.e. 'valued things that were kept or stored for extended periods' $)^{16}$ or 'curated' objects, in modern parlance. In other

\footnotetext{
10 Madrid, Museo Arqueológico Nacional, inv. no. 1969/68/155/1-4.

11 Madrid, Museo Arqueológico Nacional, inv. nos. 1979/70/Gal/T.34/2, 3, 5, 6.

12 Granada, Brazam Collection. On this krater, see Pachón, Carrasco and Aníbal (2007), with previous bibliography.
}

13 On the Phoenicians in the Iberian Peninsula, see, e.g., Aubet (2009); Celestino and López (2016); Dietler and López (2009); Vives-Ferrándiz (2005).

14 Olmos (2005) 1064.

15 See, e.g., Olmos (2003), (1996), (2003a), (2004) and (2005). A similar process of persistence of the past has been attested in the first centuries of the Roman presence (third to first centuries BC) in Spain in three necropoleis of the Baetica province (Castulo in Jaén, Baelo Claudia in Cádiz and Colonia Patricia, Córdoba) studied by Alicia Jiménez (2008). The three necropoleis show a distinctive and idiosyncratic use of 'traditional' elements (Iberian, Punic and Italic) with other more properly 'Roman’. For a summary, see also Jiménez (2006).

16 Reiterman (2016) V. 
cases, Athenian pots of advanced age - both according to a traditional linear chronology and in terms of 'social age' 17 - are deposited alongside brand-new vases of the same fabric. In the present article, I explore the reasons for and the social meaning of this consumption practice through a series of well-documented examples from Iberian necropoleis and, occasionally, settlements. I argue that the occurrence of 'aged' vases in Iberian tombs and their extraordinary survival in some settlements is the result of a conscious and motivated choice that is indicative of the existence of mechanisms of social distinction based on a diacritic use of material culture whereby access to foreign artefacts is presented as both entitling to power and as an expression of it. In addition, I argue that in post-classical times a further motivation adds on: old Athenian vases play a role similar to that of Orientalizing products earlier on and start to be used as legitimizing tools, becoming ancestry markers, i.e. they serve to root the ruling elite in a 'remote' past to justify their presence in a new territory.

\section{The Iberian Peninsula in the Iron Age and the import of Greek pottery}

The western Mediterranean during the first millennium BC encompassed a diverse and dynamic landscape of communities. One of them were the Iberians, who spoke a non-IndoEuropean language and were native to the coastal zones of southern and eastern Spain. Prior to the Roman conquest of the Iberian Peninsula in 218 BC, mainly two types of traders and colonists interacted with the Iberians: Phoenicians and Greeks, who founded colonies and trading posts all along the Mediterranean coast of the Peninsula and across the Straits of Gibraltar. ${ }^{18}$ The presence of exogenous elements and the technological innovations brought by the foreigners - mainly the adoption of iron metallurgy - converged with a time of endogenous demographic growth in Iberia and was what, according to current agreement, made possible the transition to social complexity and the development of the Iberian culture. ${ }^{19}$

The Iberian culture is far from being a monolithic reality though: the Iberians were not a unified group, but different tribes spread along the coastal zones of the Peninsula who shared a number of similar characteristics but also remarkable differences. The case studies presented in this article stem from the area of the High Andalusia, home to the peoples called Oretanii and Bastetani by later Roman sources, and from the central Spanish Levant (the regions of Contestania, Edetania and Ilercavonia). The Iberian period is traditionally divided into three development phases: Early (600/550-450/426 BC), High (450/425-200 BC) and Late Iberian periods $(200 / 50 \mathrm{BC}){ }^{20}$ The Iberian was a complex society showing evidence of social stratification and urbanization and the oppidum - i.e. fortified Iberian town - became over time the centre of reference of the new political space led by an aristocracy and

\footnotetext{
17 On 'social age', see Lucas (2004) 107-13 and Reiterman (2016) 52. I also use 'social age' to refer to objects which seem to have gone through multiple entanglements in a short period of time which 'loaded' them with an out-of-ordinary significance.

18 For a comprehensive account of the relationships of the Iberians with the Greek and Phoenician colonists, see Dietler and López (2009).

19 Sanmartí (2009) 64.

20 For an introduction to the Iberian culture and the different Iberian peoples, see Ruiz and Molinos (1998); Sánchez and Gómez (2008) and Aranegui (2012).
} 
supported by a clientele system. There is evidence that by around $550 \mathrm{BC}$ several centralized political entities with control over a large territory had already arisen, a trend which peaked in the High Iberian period during the fourth and third centuries BC. ${ }^{21}$

Greek objects started to appear in the Iberian Peninsula in the ninth century $\mathrm{BC}^{22}$ and during the Archaic period, eastern Greek productions together with Attic, Corinthian, Laconian wares and others are attested in the area. These early products, considered market-openers, are of extraordinary quality, in particular when compared with later imports, and are understood as objects of aristocratic trade. ${ }^{23}$ From the second half of the sixth century onwards, Athenian pottery starts to gain a larger share of the market until it eventually becomes the most common foreign import during the fifth and, particularly, in the fourth century BC, coinciding with the peak of development of the Iberian culture. The use of Athenian vases runs parallel with the development of the complex Iberian societies and is closely related with the emergence of the new aristocratic system centred in the oppidum, as opposed to the earlier system of divine monarchies characteristic of the Orientalizing period (with a sacred king in the Near Eastern tradition at the top of the social pyramid). Athenian pottery soon became an essential part of the relations between Greeks and Iberians and is the exogenous element that marks the new era archaeologically. Indeed, scholars understand the presence of these productions in the archaeological record in Iberia as indicative of the transition to the new socio-political system characteristic of the Iberian culture. ${ }^{24}$

Research into Athenian pottery from Spain started some fifty years ago with the pioneer work of Gloria Trías, who, trained by John Beazley himself, produced the first catalogue of Athenian pottery from the Iberian Peninsula. ${ }^{25}$ Since then, valuable efforts have been put into understanding aspects ranging from the import flows of Athenian pottery into the Peninsula, traders, middlemen and distribution (and redistribution) routes (the agreement is nowadays that most of this pottery arrived in Iberia through Phoenician and Punic actors ${ }^{26}$, regional preferences regarding shapes, the use and function of Athenian vases among the Iberians, their impact in the material culture of the native population and the effect of the Iberian demand of Athenian vases in the production of the Attic workshops, to mention just a few. ${ }^{27}$ Remarkable in this regard is Justin Walsh's investigation of the reasons why non-Greeks in the western Mediterranean and trans-Alpine Europe decided to use Greek pottery, especially

\footnotetext{
21 Sanmartí (2009) 63.

22 Eubean pottery, see González et al. (2017) 35-39.

23 Sánchez (2012) 57.

24 Domínguez and Sánchez (2001) 1 and 433-34; Ruiz and Molinos (1998) 269-83.

25 Trías (1967).

26 This is particularly clear when we look at the cargo of El Sec shipwreck (Mallorca). See Arribas et al. (1987).

27 For a state of the art, see the volumes produced by the Centre Iberia Graeca (www.iberiagraeca.org): Aquilué and Cabrera (2012) and Aquilué, Cabrera and Orfila (2017), in particular, Domínguez' contribution to the latter, with bibliography.
} 
his theory of prestige signalling through the consumption of imports, derived from Michael Dietler's work, which illuminates many aspects of my research. ${ }^{28}$

Despite the multitude of approaches, methodologies and theoretical frameworks applied to an ever-increasing body of material, there is unanimity among scholars that Greek pots were perceived as luxury goods and were used to negotiate identities, mark relationships and send signals to others: they became essential tools for the social reproduction of the Iberian system, in particular in the funerary realm. Vases originally destined for the communal use e.g. kraters - are employed by some Iberian peoples as cinerary urns lidded with bowls of Attic or local manufacture and the combination of mixing and drinking vessels is characteristic of the main Iberian necropoleis of the High Andalusia. In the realm of the tomb, Athenian vases are prestige goods that reproduce a hierarchical social system linked to the conspicuous consumption of the aristocratic elites and their clients. ${ }^{29}$ Indeed, there are clear distinctions between who receives Attic figure-decorated pottery in their tombs together with other items of the native material culture, such as stone sculpture or metal weapons, and who does not, as Ruiz' seminal study of the deposition patterns of grave goods in the necropolis of Baza well exemplified. ${ }^{30}$

The consumption practice explored in the present article shall therefore be contextualized and understood against the context of the differential use of Athenian pottery by the Iberians briefly sketched above. It is because Athenian vases were instrumental for the reproduction of a particular socio-political system that they were often curated and looked after. Likewise, the very practice of curation serves to further highlight the special place of the foreign vase among the native communities of the Peninsula. By focusing on a consumption practice that previous scholarship has largely ignored, this article offers another dimension to the ways in which Athenian vases were used to communicate ideas in ancient Iberia.

\section{Methodological notes and limitations of the study}

The presence of chronologically earlier artefacts in otherwise synchronous assemblages across the ancient Mediterranean - Greek settlements and colonies, but excluding Phoenician, Celtic and Iberian sites - has been the subject of Amanda S. Reiterman's insightful dissertation entitled Keimêlia: Objects Curated in the Ancient Mediterranean (8th-5th Centuries BC). ${ }^{31}$ Her work provides a valuable framework for our research, which conveniently focuses on an area untouched by her: the Iberian Peninsula.

\footnotetext{
28 Walsh (2014); Dietler (2010).

29 Sánchez (2012) 65.

30 Ruiz et al. (1992).

${ }^{31}$ I am grateful to Amanda Reiterman for making her work available to me.
} 
The increasing attention paid to the occurrence of anomalous objects in the archaeological record - asynchronous artefacts, repaired vessels, ${ }^{32}$ etc. - lately has to do with the surge in interest on questions of social memory and the mnemonic potential of material culture, as well as with the realization in the Social Sciences of the intimate relationship existent between people and objects and the awareness that objects 'become invested with meaning through the social interactions they are caught up in'. ${ }^{33}$ Studies on social memory and cultural identity have gained popularity since the publication of Maurice Halbwachs' works Les cadres sociaux de la mémoire (1925) and La mémoire collective in 1950.34 Halbwachs defended the collective nature of memory and its presentist character, i.e. that the past is a social construction mainly, if not wholly, shaped by the concerns of the present. His concept of 'collective memory' has been highly influential, in particular for studies focused on the use of the past to legitimise political authority, and it illuminates various aspects of my research. Equally popular has been Pierre Nora's concept of the lieux de mémoire. ${ }^{35}$ Ancient historians Jan and Aleida Assman further developed Halbwachs' ideas to propose the concept of 'cultural memory', the creation of official, mythic pasts through monuments and texts which store memories for subsequent generations. ${ }^{36}$ Paul Connerton, in turn, categorized two types of acts, intentional and habitual practices, as locales for social memory, a problematic distinction which has been contested. ${ }^{37}$

Memory studies have found a fertile ground in archaeology, a discipline devoted, as Van Dyke has put it, to 'the construction of social memory', 38 with a veritable boom in the last years. Influential archaeological memory studies have used different entry points to the subject: ${ }^{39}$ a focus on places and lieux de mémoire ${ }^{40}$ mortuary practices, including the study of

\footnotetext{
32 Some of the asynchronous objects discussed in this article do show ancient repairs but a comprehensive study of the mending habit in the Iberian Peninsula will be presented elsewhere. An overview of ancient repairs in a different medium, belt brooches, in the Iberian Peninsula has recently been presented by Graells and Lorrio (2017) 127-31.
}

33 Gosden and Marshall (1999) 170. The literature on the relationship between humans and objects is now abundant and comprises various approaches and theoretical stances, from studies focused on the biography of objects, starting with Igor Kopytoff's (1986) seminal study, or the agency of objects, e.g. Alfred Gell's (1997) fundamental new anthropological theory of visual art, to consumption and material entanglement studies like Thomas (1991), Dietler (2010) and Hodder (2012). See, e.g., Hoskins (2006); Grethlein (2008); Langdon (2001), Whitley (2013); Bielfeldt (2014).

34 For the English translation, see Halbwachs and Coser (1992).

35 These are defined as 'any significant entity, whether material or non-material in nature, which by dint of human will or the work of time has become a symbolic element of the memorial heritage of any community'. Nora and Kritzman (1996) XVII. The original work in French was published in three volumes, Nora (1984-1992).

36 Assmann (1995).

37 Connerton (1989). See Van Dyke (2019) 210.

38 Van Dyke (2019) 220. For the reasons for this boom, see Connerton (2006).

39 See a review of current trends and issues in archaeological studies of memory in Van Dyke (2019).

40 Bradley (2002). 
grave goods and manipulation of human remains; ${ }^{41}$ past in the past studies, ${ }^{42}$ in particular those focusing on the discursive and intentional use of the past ${ }^{43}$ (a field to which the current article contributes); an emphasis on persistent objects ${ }^{44}$ and on memory's counterpart, forgetting. ${ }^{45}$ For the particular case of Greece, questions of social memory have been intensively explored since the publication of John Boardman's Archaeology of Nostalgia and Alcock's Archaeologies of the Greek Past. ${ }^{46}$ Famous case studies include the investigation of Iron Age activity in Bronze Age tombs, ${ }^{47}$ the role of bodily memory and mnemonic history in the rise of the palaces on Bronze Age Crete, ${ }^{48}$ or the treatment of the remains of the Persian destruction of Athens, ${ }^{49}$ but not much attention has been paid to portable goods, especially outside sanctuary contexts. ${ }^{50}$ Yet, the mnemonic potential of the latter is even greater than that of non-portable objects because portable objects move among people and cross cultural boundaries, accumulating the memories of their successive owners and offering excellent opportunities for the activation of their mnemonic potential in the most varied ways. As they move through time and space, new meanings add to their prior associations, objects are recontextualized and get entangled in exchange networks ${ }^{51}$ and this encourages their preservation.

The main assumption that underlies the study of asynchronous objects and makes it worthy of interest is that of the intentionality, i.e. the understanding that the presence of an object with a longer than average use-life in the archaeological record is not circumstantial or unintended but the result of a conscious and motivated choice, the reasons for which - ranging from aesthetic and functional to sentimental and economic - are worthy of investigation. From the sociocultural point of view, out-of-sync objects offer a window to explore attitudes about the past in the past as well as questions of social identity and memory. As in the case of the practice of upcycling, recently analysed by Sarah Rous, the study of asynchronous objects and those which show traces of having been intentionally kept in circulation for longer than

\footnotetext{
41 Williams (2013).

42 E.g. Knight et al. (2019); Rous (2019).

43 Van Dyke and Alcock (2003).

44 Hamilakis (2013).

45 Connerton (2009).

46 Boardman (2002); Alcock (2002).
}

47 Antonaccio (1994) and Whitley (1994). More recently, for Thessaly, see Stamatopoulou (2016). For similar practices in the Near East, e.g. Pfälzner (2017).

48 Hamilakis (2015).

49 Kousser (2009). Also, Sioumpara (2016) and (2018) and Rous (2019).

${ }^{50}$ I thank Raimon Graells for bringing to my attention the discussion about foreign votives in Greek sanctuaries, especially in what concerns the fragments of Villanovan armour dedicated in the sanctuaries of Olympia and Delphi. On this regard, see, most recently, Baitinger (2011) and Aurigny (2016).

51 On entanglement generally, see Hodder (2012). 
usual - e.g. those with repairs - can serve as a focal point to integrate various disciplines, mainly archaeology, art history (reception studies) and anthropology (object biographies). ${ }^{52}$ Yet, the presence of asynchronous objects in an assemblage does not always indicate that a specific process of recollection or remembrance is at work; it is not necessarily an act of memory. ${ }^{53}$ Indeed, the deposition of foreign artefacts with signs of protracted use-lives often indicates the existence of mechanisms of social distinction based on a diacritic use of material culture. ${ }^{54}$ The study of such practice has, therefore, the potential to shed light on the status of foreign objects within the receiving communities and on locals' own attitudes to it.

This approach does not come without its problems, though. As the study of the phenomenon of residuality - objects coming from earlier to later layers - evidences, the presence of an asynchronous artefact in an assemblage may not always be intentional: the survival of an object into later generations can also be the result of mere chance and of natural or anthropogenic processes. ${ }^{55}$ This is particularly true of settlements, especially multi-phase sites, and of assemblages coming from urban excavations. Inferring some degree of intentionality is easier in the case of funerary assemblages since these are composed of objects that have been removed from circulation on purpose, passing from the systemic to the archaeological context. Most of the examples discussed in the present article come from necropoleis. We can be reasonably confident that the presence of an asynchronous object in an undisturbed burial responds to an intended action. But, while the removal of an object from circulation and its deposition in a burial is a motivated choice, nothing precludes that the very currency of the object at the time of deposition was not the result of mere chance, i.e. a specific intentionality behind the survival cannot always be detected. 56 Only a full contextual study of the particular class of object that was curated, including routes and times of acquisition, manufacture dates in Athens, frequency of curation, etc., allows for such patterns to emerge. 57

52 Rous (2019) 17, quoting Davis (2007).

53 The same applies to some cases of manipulations of ancient buildings and burial mounds, which are not always intentional attempts to reference the past but cases of expedient reuse of that building or a change in its function. See Van Dyke (2019) 211.

${ }^{54}$ See, e.g., the interesting case of the old metal objects from the sanctuary of Bitalemi at Gela (Pace and Verger 2012).

55 Theodore Peña (1998) 5 has provided a definition of residual materials as 'artifacts and ecofacts initially discarded a considerable length of time prior to their deposition in the context in which they were recovered'. The opposite scenario, i.e. objects moving from later to earlier levels is also attested and the phenomenon referred to as 'contamination' and 'intrusion'. On residuality, see, also, Evans and Millett (1992); Giudobaldi et al. (1998).

56 See, e.g., the interesting case of the so-called 'anomalie pompeiane', a group of Etruscan archaic objects and a Greek fifth-century bronze Preishydria from the Hekatombaia games celebrated at the Argive Heraion that were found in Pompeii and were discussed by Lazzarini and Zevi (1989) and Bellelli (1995). A bronze tripod from the same games was deposited in the antechamber of tomb II of Vergina, see Andronikos (1984) 165-66. I thank Raimon Graells for bringing these cases to my attention.

57 Firsthand macroscopic study of the object in search of markers of 'appreciation', such as signs of use or repair also proves extremely useful for that aim. 
One of the main obstacles we encounter for the investigation of anomalous objects in the Iberian Peninsula is the lack of contexts, a situation that, unfortunately, is not exclusive to our case. Extensive looting, old excavations and incomplete publication of the main Iberian necropoleis hinder the application of newer scholarly approaches to the study of pottery. Sometimes, though, re-excavation of old tombs and archival study of the modern history of some sites provide an avenue to rethink traditional narratives, most often built on rather limited evidence. This is the case of the necropolis of Galera (Granada), recently reexcavated by María Oliva Rodríguez Ariza and her team. ${ }^{58}$ My study and interpretation of the cups from this necropolis owes much to the new data provided by Ariza's investigation. One could only wish this example would be followed for other sites. Admittedly, the scarcity of suitable contexts results in lending much weight to a limited number of well-contextualized examples, which brings legitimate questions about the representativeness of the sample and therefore of the conclusions derived thereof. I am fully aware of this and have tried not to lose sight of the big picture during my research. Another thorny aspect of the identification of asynchronous objects is chronology. Fortunately, long years of connoisseurship studies and intense discussions of material from fixed chronological points like the deposits from the Athenian Agora have resulted in a rather solid chronology for most classes of Athenian pots. Nevertheless, it has been necessary to revise the chronology of some shapes of my sample (see infra, Cástulo cups) to be able to argue with a good degree of confidence for their extended use-life.

I am aware that placing Athenian pots at the centre of this study may be taken by some as a rather Hellenocentric move but it is one that is dictated by my own expertise in this type of material that, on the other hand, is approached from a clear post-colonial stance. 59 Such emphasis is not intended to downplay other classes of material culture. Much to the contrary, as it was mentioned above (section I), we should not lose sight of the fact that the particular use of Athenian pottery explored here is not an isolated occurrence but one aspect of a wider phenomenon of re-use of old objects, artistic belatedness and even intentional older-looking but newly-made creations in the Iberian Peninsula which merits a multidisciplinary research project of its own. Also, this behavior regarding Mediterranean imports is not exclusive to the Iberians, but is widely attested among other peoples of Iron Age Europe, with famous examples among the Hallstatt and La Tène cultures, ${ }^{60}$ and also in Sicily. ${ }^{61}$ Whether the focus on the Attic material might be questionable, the approach to the material is far from Hellenocentric. Indeed, adopting the premise that 'when artefacts move beyond the borders of the producing society and are integrated into the material culture of other social groups,

\footnotetext{
58 Rodríguez (2014).

59 Similarly, also Walsh (2019) 289.

60 Fischer (1973); Guggisberg (2004). Most recently, on Mediterranean imports in Iron Age Europe, see the three volumes arising from the project BEFIM, Bedeutungen und Funktionen mediterraner Importe im früheisenzeitlichen Mitteleuropa, led by Philipp Stockhammer (https://www.befim.gwi.uni-muenchen.de). Stockhammer and Fries-Knoblach (2019a, b) and van Gijn, Fries-Knoblach and Stockhammer (forthcoming).
}

61 E.g. the use of archaika in Monte Iato: Kistler et al. (2017). 
they acquire a new meaning and play a new role', ${ }^{62}$ I understand Athenian pots here not so much as Athenian objects any more but as Iberian or 'Iberianized' - hence the term 'appropriation' in the title 63 -. The agency of the Iberian consumer is therefore emphasized throughout the study.

Finally, it must be noted that the occurrence of asynchronous Attic vases in the Iberian archaeological record, albeit a significant practice commonly mentioned in Spanish scholarship and more usual than once thought, it is not common. Previous studies on Greek material from the Iberian Peninsula have revealed the main guidelines to understand how Athenian pots were traded and used among the Iberians - to different degrees of completeness for the various geographical areas - and the image that emerges from them is one of chronological and morphological homogeneity of the pottery repertoire within the different Iberian regions. ${ }^{64}$ But once this essential groundwork has been done, I believe it is time to try new approaches on old material, to read between the lines of the archaeological record and look at what can be labelled as 'anecdotes' or 'oddities' because, as Pierre Rouillard rightly stressed: it is precisely 'les usages "marginaux" qui nous aident à percevoir le status du vase grec'. ${ }^{65}$

\section{Athenian cups in the Iberian archaeological record}

In the present article I explore the possible reasons and meaning of the consumption practice of the delayed deposition of Athenian pottery in Spain through eight case studies focused on drinking cups, both black-gloss with inset lip (Cástulo cups) (5 examples) and red-figure type B cups ( 2 examples), plus a set of six kraters from an extraordinary first-century BC tomb. Although there are other pottery shapes that occasionally survive into later contexts, like some bowls with outturned rim in Murcia and Valencia or some kraters from Andalusian burials that raise concerns about their chronological alignment with the rest of the assemblage, ${ }^{66}$ it is usually cups cropping up as out-of-synch objects. This is undoubtedly due to cups - or drinking-related vessels more widely - being the most common Athenian import in the Iberian Peninsula, ${ }^{67}$ which, in turn, is indicative of the very same particular appreciation of the shape that the practice of curation discussed in the present article suggests. Ceramic or metal vessels related to food production, preparation or storage are, on

\footnotetext{
62 Arafat and Morgan (1994) 108.

63 On appropriation, see, e.g., Vives-Ferrándiz (2005), in particular 35-37, 46-48, 219-27 and (2010).

64 Trías (1967); Rouillard (1991); Domínguez and Sánchez (2001); Walsh (2014). José Miguel García Cano García (1999) - estimated in $0.13 \%$ the cases of tombs with assynchronic assemblages in the region of Murcia.

65 Rouillard (2009) 374.

66 E.g. the kraters from tomb 43 of Baza. See Sánchez (2017a) 191-92 and (2017b) 98-101.

67 Before the Cástulo cups, it was the type Bloesch C cups in the late sixth early fifth century that were widespread in the Peninsula. On the distribution of cups in the Iberian Peninsula see Rouillard (1991) 158-66 and in the West more generally, see Walsh (2014) 158-63, also 103-108 and 110-23 (on pottery and banqueting). On the later cups of the Group of Vienna 116, see Rouillard (1975).
} 
the other hand, amongst the most common types of heirlooms worldwide 68 because they are emblematic of economic success, social affiliation and political rank and therefore considered worthy of heirloom status.

The Attic black-gloss cups with inset lip were a common production in the western markets. Brian Shefton named them Cástulo cups after the site of Cástulo, in Jaén, which has yielded a good number of them. ${ }^{69}$ Taking a rather colonialist approach, he most famously explained their popularity alluding to the sturdiness of the shape, suitable for a barbarian banquet where the cups might have had to survive being dropped on the floor or indeed being used as 'weapons during brawls on such occasions'. ${ }^{70}$ Spanish scholarship has long since called attention to the chronological problems posed by the presence of these cups in the Iberian archaeological record. There is a time lag of some 20-25 years (or more) between their Agora dates, which might not be very far from their production dates, and their date of deposition in Iberian contexts. The chronology of the Agora examples spans the years 480 to $425 \mathrm{BC}$ with red-figure versions going down to the first quarter of the fourth century ${ }^{71}$ but the dates proposed for the Spanish examples are one or two generations later, ca. 440-350 BC. Carmen Sánchez argued for an extended production of the shape targeted to the Iberian market, ${ }^{72}$ which I think is plausible for the later all-black examples from fourth-century contexts. My research, in turn, focuses on the old type of Cástulo cup, that which exhibits a reserved panel between the handles and reserved underside and outside face of the foot. This type was seemly not produced in Athens much beyond the middle of the fifth century but appears in archaeological contexts of the last quarter of the century in the Peninsula. I have recently revised the chronology of the Cástulo cups in Spain and argued that the examples of the old type did indeed arrive in the Peninsula in dates that agree with the Agora chronology, i.e. by the mid-fifth century. ${ }^{73}$ On close inspection of the evidence, I subsequently argued that (1) the late deposition of some examples of the old type, in particular in funerary contexts of the High Andalusia, is due to a particularly long period of use in their respective oppida and (2) that a number of symbolic aspects and the diacritic use of pottery along the lines of the

\footnotetext{
68 Lillios (1999) 252.
}

69 Shefton (1982), (1986) and (1990a, b). In Spanish and French scholarship before Shefton - and even after - it is not uncommon to find it referred as shape Lamboglia 42A and, occasionally, as shape Morel 4271 ai. Lambogila (1952), Morel (1981).

70 Shefton (1990a) 88. It is important to note that while sturdiness might have played a role in their wide distribution and popularity, it was surely not the only one, especially if we take into account the wide distribution in Spain of their successors, the cups of the Group of Vienna 116 and their almost egg-shell walls.

71 Sparkes and Talcott (1970) part 1, 268. BAPD 340082. The red figure examples had a more restricted distribution, with find-spots in Greece - unlike the black-gloss ones - and Italy. Sparkes (2016) n.16.

72 Sánchez (1992) 332. Contra Gracia (2003) 58. See, also, Gracia (2005).

73 See full discussion in Rodríguez (2019). 
prestige-goods theory are behind their curation and deposition in a number of remarkable tombs of the area, in particular in the necropolis of Galera (Granada). ${ }^{74}$

The second type of cups that shows evidence of having been occasionally curated is type B cups. These are stemmed cups with neither offset lip nor fillet at the top of the stem, which results in a rather elegant flowing curve profile. Arguably the most popular cup shape in redfigure, it is very well represented in the home market, especially in the Athenian Agora. 75 They are nevertheless rare findings in the Iberian Peninsula outside the Greek colony of Ampurias (Emporion) ${ }^{76}$ and are usually regarded as 'élite-tied luxury imports',77 characterized by Shefton as a group of 'high grade, finely painted red-figure vases of the kind one would expect to see in major destinations of Attic export'. ${ }^{78}$ They are fragile and unsuitable for shipment - they cannot be stacked - , what explains their limited trade in the Peninsula, especially when compared with the later stemless cups of the Group of Vienna $116^{79}$ or with the Cástulo cups. They pose a too-high risk of breakage. According to Shefton, the motivation for incurring this additional risk 'must have been especially powerful' 80 and it is argued that they could have functioned as personal gifts to strengthen trade relationships. Type B cups are the followers of a group of earlier 'exclusive' stemmed cups that made their way into the Peninsula in the sixth and fifth centuries BC, such as Eucheiros' superb Little Masters lip cup from Medellín (Badajoz), ${ }^{81}$ or even the rather sloppy but nevertheless remarkable type $\mathrm{C}$ cup by the Pithos Painter from the funerary monument of Pozo Moro (Chinchilla de Montearagón, Albacete). ${ }^{82}$ Their exclusivity and significance in Spain is reinforced by the deposition patterns of the few examples found in context outside Ampurias, three of which will be discussed in this article.

\section{Old Athenian vases among the Iberians - case studies}

The eight case studies presented here are organized in two groups according to the inferred public or private character of the occasion when the deposition took place (on the rationale of this, see further in the discussion section). I have chosen this organization because I think that

\footnotetext{
74 Briefly summarized, the prestige-goods theory as formulated by Frankenstein and Rowlands (1978), esp. 7584 , posits that economies political power is associated with control over the procurement and distribution of exotic goods, which are assigned high status.

75 Moore (1997) 68-71.

76 Miró (2006) records 658 fragments individualized as single stemmed cups in her catalogue of the Athenian red-figure pottery from Ampurias. Unlike in the Peninsula, stemmed cups are the most common Attic imports in Etruria.

77 Shefton (1995) 131.

78 Shefton (1995) 130.

79 On the distribution of this type of cup in the Iberian Peninsula, see Rouillard (1975).

80 Shefton 1995, 132.

81 Madrid, Museo Arqueológico Nacional inv. no. 1969/61/1, BAPD 5523.

82 Madrid, Museo Arqueológico Nacional inv. no. 1979/104/1973/402, BAPD 11671, Almagro-Gorbea (2009a).
} 
such character and, therefore, the implied audience of the act of deposition is important to understand the motivation behind it and the role of the object. The first group comprises oldobjects deposited in tombs of Iberian princes or high-rank individuals with socio-political influence and a case of deposition in an urban setting. The second includes two funerary depositions in a more private context. If we bear in mind the estimated time elapsed between manufacture and deposition, two further scenarios can be identified: cups with an intragenerational circulation, i.e. their lifespan comprised one or two human generations ( $c a$. 25-50 years) and cases of cross-generational pots with centenary lives. Each case is presented in a descriptive way providing as much contextual information as possible, followed by an ample discussion section and brief concluding remarks.

\section{V.1. Public display of old objects}

\section{V.1.1. Cases 1 and 2: Cástulo cups from tombs 11 and 20 of the Necropolis of Tútugi (Galera, Granada). ${ }^{83}$}

The first two case studies are Cástulo cups from the most remarkable tombs of the necropolis of Tútugi: numbers 11 and 20,84 which included only one other item of Athenian pottery: a red-figure bell-krater ${ }^{85}$ and polychrome Iberian vessels. Current agreement among Spanish archaeologists is that tomb 20 belonged to either the founding couple of the lineage or to the female member of the couple only (according to this view, the man would be interred in tomb 11). ${ }^{86}$ It is regardless the most important burial of the site - the one structuring the use of the space of the necropolis - and went through two construction phases: it was first a tomb that was periodically opened for the performance of various rituals and was later converted into an open-air sanctuary surrounded by a red painted platform in the shape of an ox-hide, a symbol of Phoenician origin that harks back to older Orientalizing altars of the type, the most famous of which is that at the Phoenician sanctuary at El Carambolo (Seville). ${ }^{87}$ The material assemblage likely belongs to the first phase of the structure and included, among others, the famous Lady of Galera ${ }^{88}$ (fig. 3). This is an alabaster statuette of the goddess Astarté sitting on a throne flanked by two sphinxes. She holds a bowl in her hands, her breasts are pierced

83 Tútugi is the Iberian name of the settlement at Cerro del Real, later occupied by the Romans, and of the associated necropolis. The archaeological site is located in the surroundings of the modern village of Galera, in the province of Granada, and also comprises a peri-urban sanctuary. In this text, Tútugi and Galera will be used indistinctively to refer to this site.

84 These tombs are all in the sectors I and II of the necropolis, according to their excavators the area 'preferred by the better off families of Tútugi'. Cabré and Motos (1920) 19.

85 Fragments of a red-figure pottery were found in tomb 20 during the excavation of 2006 by Rodríguez Ariza and her team. The krater might have been destroyed when the tomb was looted. Rodríguez (2014) 256. The presence of the krater in the tomb therefore invalidates the theories that hypothesized about a conscious attempt to avoid fully incorporating the new fashions from Greece into the burial, similarly to the situation encountered in tomb 155 of Baza, home to the Lady of Baza.

86 Rodríguez (2014) 260-1; Rodríguez and Pérez (2013) 444. On the tomb 20, see also Rodríguez et al. (2008).

87 On the sanctuary of El Carambolo, see, e.g., Fernández and Rodríguez (2005), Escacena, Fernández and Rodríguez (2007) and Escacena and Amores (2011). On ox-hide altars and their symbolism in the Iberian Peninsula, see Almagro-Gorbea et al. (2011-12).

88 Madrid, Museo Arqueológico Nacional inv. no. 33438. 
and the top of her head is open; it was clearly intended as a libation device. This was a curated object in its own right and has been interpreted as part of the sacra gentilicia of the royal family of Galera. ${ }^{89}$ It shows signs of wear over its body and an intentional alteration in the area of the handles that speaks of its long history: according to Martín Almagro-Gorbea, ${ }^{90}$ it would have been manufactured in a north-Syrian workshop in the eighth century BC. The Cástulo cup, ${ }^{91}$ (fig. 4) heavily misfired but with a reserved panel between the handles, was an object of a certain antiquity too: the date proposed for the tomb is the last decades of the fifth century, a time when the all-black cups were the norm.

The association of a Cástulo cup with reserved panel ${ }^{92}$ and a red-figure krater also occurs in tomb 11, of another prominent member of the lineage of Tútugi, either the male founder or a close relative. ${ }^{93}$ Like tomb 20, it underwent two construction phases. First, a burial mound with ritual activity in its surroundings ${ }^{94}$, it collapsed shortly after its construction and a second structure was built on top, a funerary chamber surrounded by an ox-hide shaped platform. ${ }^{95}$ The published grave goods, including cup and krater, come from the upper structure, discovered in the early twentieth-century excavations. ${ }^{96}$ The first tumulus was only found during the works of the 2000s and it contained a few fragmentary objects. This material poses a problem because it is chronologically later (early fourth-century) than that of the upper chamber, which was dated to the second half of the fifth century after the red-figure krater attributed by Beazley to the Group of Polygnotos ( $c a .440$ BC). ${ }^{97}$ The architectural characteristics of the chamber and part of the grave goods point to a date in the late fifth century, though. To sort out the chronological riddle, the excavators propose that the assemblage from the upper chamber was already in the first tomb and was transferred to the chamber when the tumulus collapsed. ${ }^{98}$ This scenario is plausible but it is worth noting that the second half of the fifth century date derives exclusively from Polygnotos' krater and from

\footnotetext{
${ }^{89}$ Almagro-Gorbea (2009b) 25

90 Almagro-Gorbea (2009b) 25.

91 Madrid, Museo Arqueológico Nacional inv. no. 1979/70/GAL/T20/9. The handle of the cup, which was missing, was found in the re-excavation of the tomb. This cup is presently on display in the museum so I could not inspect it myself, but Sánchez does not refer any signs of wear on it. Domínguez and Sánchez (2001) 22324.

92 Madrid, Museo Arqueológico Nacional inv. no. 1979/70/GAL/T11/3.
}

93 In 2004 it was published that the remains might belong to a woman - Pereira et al. (2004) 84 - but such an identification has not been confirmed and the masculine gender of the deceased seems more likely according to Rodríguez (2014) 261. Nevertheless, the gender question is only of tangential importance for the matters that I am exploring here.

94 Rodríguez (2014) 54.

95 Rodríguez (2014) 52-56.

96 Cabré and Motos (1920).

97 Museo Arqueológico Nacional, inv. no. 1979/70/GAL/T11/2, BAPD 213687.

98 Rodríguez (2014) 62. 
the conventional dating of the old Cástulo cups. The remaining material of both the upper chamber - e.g. the Iberian ash-urn associated to the Athenian pottery 99 - and the earlier tumulus can be more comfortably dated in the late fifth-early fourth century. If it were not for the krater and the cup, both phases would have been dated to the end of the fifth or early fourth century, in line with tombs 20 and 34. Therefore the evidence suggests that both vases, krater and cup, are curated objects. ${ }^{100}$ Indeed, if this tomb belonged to the male member of the couple, associated with the woman in tomb 20, one might argue that the Athenian objects of both tombs were part of the family 'cup-board' and would have amassed almost half a century of history before making their way to the tomb. ${ }^{101}$

The emphasis of both tombs on the same subject, i.e. libation, would also strengthen this hypothesis. Polygnotos' krater from tomb 11 carries a scene of a youth on horseback and a Nike performing a libation with oinochoe (wine jug) and phiale (libation bowl) on the side A and three draped youths conversing on side B. As for tomb 20, Olmos understood the exotic paraphernalia of the burial as biographical objects of a priest/priestess: glass amphoriskoi from the East, the cup, the phiale mesomphalos and the statuette. ${ }^{102}$ Almagro-Gorbea opts for the identification of the deceased as a basileus kai ieros instead; he understands the grave goods as ritual objects linked to a practice of sacred anointing of kings and deities and the performance of libations attested in Syrio-Phoenician religion that would have survived into the Iberian period. ${ }^{103}$ The presence of a krater in this context should come as little surprise: the occurrence of krater and cup in an Iberian tomb does not necessary allude to the actual practice of the symposium and cannot be taken as a sign of Hellenization. Rather, these shapes are usually invested with different meanings and uses in the Iberian context. ${ }^{104}$

\section{V.1.2. Case 3: Castellones de Ceal (Jaén)}

\footnotetext{
99 Pereira et al. (2004) 84.
}

100 A similar pair of red-figure krater and Cástulo cup is attested in tomb 34. The krater (ca. 440-435 BC) has been attributed to the Painter of Munich 2334 and the tomb is dated to the end of the fifth or early fourth century, being the krater an 'antique'. The Cástulo cup belongs to the all-black type and therefore its chronology falls nicely within the date of the tomb.

101 The cups show slight morphological differences that suggest they are not part of the same production batch. See drawings in Domínguez and Sánchez (2001) no.236=tomb 20, no.234=tomb 11.

102 Olmos (2004) 229-32.

103 Almagro-Gorbea (2009b) 25-27.

104 The recent findings of the team of the Instituto Universitario de Investigación en Arqueología Ibérica of the University of Jaén at the sanctuary of Puente Tablas (Jaén) are relevant in this regard. The residue analysis has revealed remains of native sulphur in both the bell-krater and one of the Attic cups from the sanctuary, what is indicative of their function as containers of purified water during religious libation ceremonies. See Parras et al. (2015) 511, 517. The iconography of the krater is very suggestive too and would fit nicely in a ritual context; it is very fragmentary but several signs allows the reconstruction of a scene of sacrifice on an altar - meat on spits - and before a herm of either Dionysos or Hermes, iconography popularized by the Splanchnopt Painter in the early classical period. I thank Carmen Rueda for the information about these findings, the article, and her warm hospitality. She also kindly let me examine the fragmentary krater at the Institute in Jaén in 2017. 
The tombs from Galera bring to mind a case of a possible prolonged use of an Athenian cup a red-figure stemless cup this time ${ }^{105}$ - in another prominent tomb of the area: number 11/145 of Castellones de Ceal (Jaén).106 This necropolis offers few opportunities for the identification of asynchronous artefacts because only three of its burials include more than one Attic vase. 107

Tomb 11/145 is a well-accomplished funerary structure with two chambers, one below with grave goods pertaining to the deceased and an upper chamber with offerings left by relatives and/or friends after the funeral. The material in the lower chamber, carefully deposited, included the funerary urn with the remains of the deceased (a 30-50 years old male) and some personal objects like gold earrings, a silver ring, bronze tweezers, a bead and a button. Besides the urn, there was a red-figure stemless cup, three Iberian urns with red painting on plaster, a local bowl, chicken eggs shells, burnt and unburnt animal bones and remains of a seashell. ${ }^{108}$ The cup and the bowl were closely associated to the fauna remains, possibly a sheep deposited as part of the ritual. The role of drink and food was paramount in the funerary ritual of the Iberians ${ }^{109}$ and these remains point to some sort of funeral meal at the tomb. The upper chamber was separated from the lower by a wooden floor and contained four bowls, an inkpot with some fragments of eggshells inside and further burnt bones and eggshells. Carbon-14 analysis of the wood from the structure gives a date of $c a .370 \mathrm{BC}$ for the construction of the tomb. 110 This chronology accords well with the dating of the Iberian pottery, but the red-figure cup should be dated to the last decades of the fifth century.

The inside of the cup bears a representation of a youth draped in himation and looking to the right, next to the terma of the palestra. ${ }^{111}$ The outside did not receive decoration. It is one of the earliest Athenian pots from the necropolis, together with a small group of three other redfigure cups dated to around $420 \mathrm{BC} .{ }^{112}$ All present a decorated inside and glazed outside: two with a draped youth, one looking to the left, the other looking towards an altar at the right, and the third bears an owl between branches. The one with the youth at the altar comes from tomb IX, found in 1956, and the remaining two are stray finds also from early excavations in the necropolis. Further to these, a curated old type Cástulo with abundant marks of use on the

\footnotetext{
105 BAPD 9036436.

106 On this necropolis, see Chapa et al. (1998). On the tomb, see also, Chapa et al. (1991).

107 Unfortunately, the chronology for local Iberian materials relays heavily on the dates provided by Athenian pottery.

108 Chapa et. al. (1991) 337-38.

109 Chapa et al. (1991) 340.

110 Chapa et al. (1990); Chapa et al. (1991) and (1998) 105-9.

111 BAPD 9036436.

112 Domínguez and Sánchez (2001) nos. 272, 273 and 271.
} 
inside comes from tomb B, one of the first graves excavated in 1955, dated to the first quarter of the fourth century. Another early Cástulo has no context. ${ }^{113}$

\section{V.1.3. Case 4: Type B cups from La Albufereta (Alicante)}

Athenian pottery had a remarkably long life in the Albufereta, the necropolis of the Tossal de Manises (Alicante). Jorge García Cardiel has recently revised the findings and related literature and argued that half of the fifth- and fourth-century Athenian vases from datable funerary contexts were deposited in the second half of the third century (the other half comes from assemblages with undiagnostic material). ${ }^{114}$ Worth mentioning is the case of two redfigure type B cups by the Painter of London E $106^{115}$ from the votive deposit L127A, previously identified as a tomb. This deposit yielded a large amount of material, including ceramic censers in the shape of a female head,116 unguentaria, terracotta female figurines, glass beads, loom weights, Campanian pottery, iron weaponry, remains of a chariot, gold earrings, fibulae, a decorated pithos, a double vase, eggshells, knucklebones, ivory appliqués and a bronze medallion embedded with a glass relief of a bearded face. ${ }^{117}$ On top of these are the two red-figure type B cups and a lekanis lid attributed to the Group of the Vienna lekanis (fourth century BC). With the exception of these vases, the chronology of the material falls within the third century.

The cups are decorated inside and outside (fig. 5). ${ }^{118}$ One bears a scene of the departure (or return) of the warrior on the tondo, with a youth with spears, sandals, chlamys and petasos sitting at a pillar next to a woman with phiale in the right hand. ${ }^{119}$ Outside, a libation scene on each side - once next to a column - with a woman holding phiale and oinochoe between a youth in walking attire and a bearded man draped in himation and leaning on a staff. The second one bears athletic scenes: 120 inside, a crowned naked youth holds necklace or wreath at a post next to a woman; outside, two palestra scenes with youths, some of them naked, and aryballoi suspended. The lekanis lid has an animal frieze with dogs, panther, lion and griffin. ${ }^{121}$ The Painter of London E 106 had a rather western distribution and his work

\footnotetext{
113 Jaén, Museo Provincial, inv. nos. CE/DA00008 and CE/DA00299.

114 García (2017) 219. The revision and full publication of the material from the necropolis has been the subject of Enric Verdú's PhD. See Verdú (2014). A revised version of the thesis was published in 2015 - Verdú (2015) but I have not been able to access this publication.
}

115 BAPD 250080 and 9023186.

116 On these, see Sala-Sellés and Verdú (2014); Moratalla and Verdú (2007).

117 Verdú (2014) 1868-80.

118 For an iconological reading of the cups within the Iberian context, see Olmos (2000-2001) 361-63.

119 BAPD 250080.

120 BAPD 9023186.

121 BAPD 9035813 
concentrates in Ensèrune (France). ${ }^{122} \mathrm{He}$ was part of the sub-Meidian group and is also attested in Ullastret and Ampurias, ${ }^{123}$ which was the likely origin of the cup from La Albufereta. It is the only example of the painter attested to the south of the colony, what, as in the case of the cup from Puig de la Nau (see below), speaks of an exchange with a highranking individual in the fifth century $\mathrm{BC}$.

According to Cardiel's suggestive hypothesis, the deposit L127A would be the result of a ritual act involving fire performed by the local elites at the end of the third century $\mathrm{BC}$ in the context of the turmoil generated by the Carthaginian presence in the area. ${ }^{124}$ The settlement of El Tossal de Manises was founded around that time with population coming from the nearby Tossal de les Basses, ${ }^{125}$ its ruling group being either 'appointed' by the Carthaginians or on good terms with them. Displaced to a new settlement, these elites used material culture to legitimize their newly acquired power by presenting themselves as the natural heirs of a distant prestigious past and as privileged actors in the international trade network. ${ }^{126}$ To this aim they appropriated the sacred space of a $c a$. two centuries old necropolis and disposed of an impressive quantity of expensive exotic items. The deposit L127A is therefore the result of a careful act of conspicuous consumption. According to García Cardiel, the person, family or social group behind such an act could have been either ethnically Carthaginian - he identifies several Punicizing traits in the complex - or a descendant of the old Iberian aristocracy. Whoever they might be, they made a careful use of material culture; alongside current objects from foreign markets, they also disposed of relics: an old Iberian chariot and two bicentenary Attic red-figure type B cups.

\section{V.1.4. Case 5: the kraters from Piquía (Arjona, Jaén)}

In 2010, the funerary chamber of the Iberian prince Iltirtiitir, and - possibly - his wife, who died in the first half of the first century BC (when the Peninsula was already under Roman rule) was discovered in the municipality of Piquía (Arjona, Jaén).127 The tomb was profaned shortly after the burial.128 The remaining material was subsequently reunited and a suovetaurilia was performed to revert the sacrilege. ${ }^{129}$ The grave goods are exceptional: six fourth-century Athenian red-figure bell-kraters (fig. 6) - two of them very fragmentary - , a

\footnotetext{
122 See distribution maps in the BAPD.

123 Miró (2006) 208-11.

124 García (forthcoming). I thank Jorge García for sharing his manuscript with me ahead of publication.

125 There is indeed one instance of a Type B cup (a fragment of the foot) at the Tossal de les Basses: Alicante, Museo Arqueológico sn (CIG8053).

126 García (forthcoming).

127 Olmos et al. (2012); Ruiz et al. (2016); Rueda and Olmos (2016).

128 Inside the tomb were found fragments of various grave goods also documented four meters away from the chamber. See Ruiz et al. (2016) 359.
}

129 Ruiz et al. (2016) 360-61. 
column krater, 130 and a small fragment of a red-figure cup; Iberian artefacts, including a processional chariot; Roman weaponry; and an Iberian lead plaque with south-eastern Iberian script recording the name of the deceased. ${ }^{131}$

The kraters have been attributed to the Oinomaos and London F64 painters, from Beazley's Plainer Group (early fourth-century BC), and to the Black Thyrsos Painter (one of his first productions, according to Sánchez, $c a .370$ BC). 132 The iconography of some of them is highly unusual, both in the Iberian Peninsula and elsewhere. ${ }^{133}$ This is the case of the most exceptional of the six kraters, which bears a scene of Herakles in a naiskos on side A. ${ }^{134}$ It is a large vase, $40 \mathrm{~cm}$ height, of good craftsmanship and singled out by an egg frieze along the rim. It shows complex scenes on both sides revolving around a seated figure in the centre. On side A, Herakles is surrounded by Nike performing a libation, Apollo, Palemon, Eros and satyrs, while on side B, Dionysos is being crowned by a flying Nike. 135

Another unusual vase is the krater of 'the wedding of Herakles'. ${ }^{136}$ On side A, Herakles rides a centaur playing a lyre, surrounded by a maenad holding a tumpanon and led by Hera, who illuminates the way with torches. Zeus sits on the right. The scene depicted is Herakles en route to his wedding with Hebe, a theme that is seldom represented in vase painting, with only one iconographical parallel: a later krater by the Filottrano Painter. ${ }^{137}$ The third krater depicts an also unusual scene of 'marriage' between a male and female figure of difficult identification. ${ }^{138}$ Paris and Helen have been suggested ${ }^{139}$ but I disagree with that identification; various signs like the ubiquitousness of the laurel wreaths seem to point to Apollo instead. The fourth krater bears a more usual representation of the feminine bath at a laver with Eros pouring water on the naked female. ${ }^{140}$ To the sides, three women, one naked and holding a mirror, the other two holding boxes, one of them seated. A satyr gesticulates as he leaves the scene to the right. The remaining two kraters are fragmentary but the scenes can

\footnotetext{
130 Judging by the thickness of the fragment preserved, I think it might belong to a pelike instead.

131 Ruiz et al. (2016) 361-68.

132 Sánchez (2014) 270.

133 For the iconography of the kraters, see competing interpretations by Olmos and Rueda (2016) and Sánchez (2019).
}

134 BAPD 9030004.

135 Carmen Sánchez is working on the iconography of this and other kraters from the Iberian Peninsula in the framework of her research project Visual Narration in Athenian Vase Painting: Red-Figure Kraters from Iberian Contexts (PGC2018-095530-B-I00).

136 BAPD 9030005.

137 BAPD 218250.

138 BAPD 9030008.

139 Olmos and Rueda (2016).

140 BAPD 9030007. 
be reconstructed: one bears a komos ${ }^{141}$ and the other a banquet scene. ${ }^{142}$ We will come back to the iconographical programme and what it can tell us about the origin of the kraters in the discussion (section VI.4).

Piquía is a highly relevant and extreme example of the presence of out-of-synch Athenian pottery in the Iberian archaeological record. Such a pronounced timespan between the production and deposition dates of an Athenian vase is uncommon, though. Apart from Piquía and La Albufereta, we count with Athenian black-gloss pottery in destruction levels of some settlements in Valencia (Puntal del Llops, Edeta/Tossal de Sant Miquel or Los Villares de Caudete de las Fuentes) ${ }^{143}$ and two tombs in Murcia (tomb 55 from the necropolis of Poblado at Coimbra del Barranco Ancho and number 184 of El Cabecico del Tesoro). ${ }^{144}$

\section{V.1.5. Case 6: Puig de la Nau (Benicarló, Castellón)}

The habitation site of the Iberian township of El Puig de la Nau (Benicarló, Castellón) yielded the very large-sized red-figure cup attributed to the Penthesilea Painter ( $c a .460)$ (figs 7 and 8). ${ }^{145}$ Although chronologically in line with the fourth occupation phase of the settlement (500-450 BC), it appeared scattered in fragments in the deepest level of street B, a context of the second half of the fifth century. ${ }^{146}$ The cup is relatively complete, with some $60 \%$ of the fragments present, some of which show traces of burning. It bears a palestra scene on the inside, with two youths, one fully draped and one with stick, at a post; the athlete kit hangs in the background. Draped youths decorate the outside. The Penthesilea Painter is only attested in good numbers in Ampurias (eleven stemmed cups) ${ }^{147}$ and our cup, like the fragmentary one from El Llano de la Consolación (Albacete), ${ }^{148}$ undoubtedly arrived in E1 Puig through Ampuritan agency. It is a remarkable piece on several grounds, mainly its size, $37 \mathrm{~cm}$ of diameter ( 47 with handles), and the restoration holes that it exhibits.

The cup from El Puig can be classified within the category of Parade Cups, the defining feature of which is a diameter larger than $35 \mathrm{~cm} .{ }^{149}$ Among the 658 cups or fragments of Attic cups recorded in Ampurias and published in Miró's monograph of the red-figure pottery from

\footnotetext{
141 BAPD 9030006.

142 BAPD 9030009.

143 Puntal del Llops: Bonet and Mata (2001) 53, fig.56.3048, 147-48; Edeta: Bonet (1995) 394; Los Villares: Mata (1991) 193-95.

144 García (1999).

145 Castellón, Museo de Bellas Artes inv. no. 1762, BAPD 6346, Sanmartí-Grego and Gusi (1976). I thank Arturo Oliver Foix for the photographs of this cup.

146 Oliver and Gusi (1995) 175-76; Sanmartí-Grego and Gusi (1976); Grau et al. (2005) 63-64; Domínguez and Sánchez (2001) 54, fig.48.1; Oliver (2006b) 188-90.

147 Miró (2006) 181-82.

148 Valenciano (2000) 364-65.

149 Tsingarida (2009) 195-97.
} 
the site, none of them gets close to the diameter of our example. According to Athena Tsingarida, Parade Cups were a rare but characteristic production of the Late Archaic period (525-480 BC) with 28 examples recorded in her 2009 publication. ${ }^{150}$ Martin Robertson suggested that the oversized phialae were intended for the use of heroes and gods, a dedicatory purpose that Tsingarida argues must also apply to the Parade Cups, linking both with the religious practice of the Theoxenia. ${ }^{151}$ A different function is sought for them in the export market - many come from Etruria -, where they would 'help in asserting the status of the Etruscan owner'. ${ }^{152}$ In the Classical period, Parade Cups are even rarer, with only five known examples, among which a cup from Spina stands out. ${ }^{153}$ Remarkably, this is also a work of the Penthesilea Painter, but it differs from the cup of El Puig in style and quality. While the Italian example aligns well with the late archaic Parade Cups in the elaboration of the decoration, detail work and iconographical complexity (Theseian cycle), the cup from Benicarló only ticks the box, as it were, of the size. Indeed, as Sanmartí and Gusi rightly saw when they published the cup, it is closer to two other works by the painter in Paris and Munich. ${ }^{154}$ But whereas not particularly elaborated in terms of style and iconography, the Spanish example stands out for the singularity of its shape and technique among the bulk of the Attic pottery from the site, mainly black-gloss pottery and the occasional decorated fragment. ${ }^{155}$

The El Puig de la Nau cup is also remarkable because it was mended in antiquity. It shows abundant drilling holes but no remains of metal, what led Sanmartí to argue that it was never really repaired. ${ }^{156}$ Nevertheless, the absence of lead clamps is not significant because these are rarely preserved. We cannot forget either that often repairs on pottery were done by tying the sherds together with perishable material - and thus not preserved - like stringing leather, rope or another organic material through the holes. ${ }^{157}$ Despite this being considered a very early repair practice by Dooijes and Nieuwenhuyse, ${ }^{158}$ my recent examination of dozens of purported repair holes in pottery from Ampurias and Ullastret suggests that it might have been more usual for Athenian pottery, at least in some areas of the Iberian Peninsula, than

\footnotetext{
150 Tsingarida (2009) 186.

151 Sanmartí-Grego and Gusi (1976).

152 Tsingarida (2009) 197.

153 Ferrara, Museo Nazionale di Spina inv. no. 44885, BAPD 211599, Alfieri (1959).

154 BAPD 211569 and 211566.

155 Oliver and Gusi (1995) 176; Sanmartí-Grego (1976).

156 Sanmartí-Grego and Gusi (1976) 208.
}

157 For pottery repairs, see, e.g., Bentz and Kästner (2007); Dávila Buitrón (2016); Dooijies and Nieuwenhuyse (2007) and (2009); Elston (1990); Hemelrijk (1986); Pfisterer-Haas (1998) and (2002); Rotroff (2011); SchöneDenkinger (2007); Nadalini (2003); Peña (2007).

158 Dooijies and Nieuwenhuyse (2007) 16. 
commonly held. ${ }^{159}$ Coming back to the Penthesilea cup, there is evidence that it was indeed repaired: some repair holes are cut in half by breaking lines (fig. 8) and that would not be possible if the fragments were not together when the cup underwent its final breakage. Some holes also show burning traces incompatible with an attempted repair post-breakage. 160 Joining burnt and unburnt fragments evidence a secondary cremation of the cup. Whereas a desire to repair, i.e. to extend an object's use-life, can be linked to restricted supply, as it surely applies to the Benicarló cup, it is worth noting that Athenian cups in Ampurias were as intensively repaired and 'curated' as elsewhere in the Peninsula, even though there was no shortage of them. ${ }^{161}$

The Penthesilea Painter cup is a one-off in El Puig de la Nau. The material culture of the site is unremarkable, typical of a loosely hierarchical society. The excavators contrast the seeming 'material poverty' of their inhabitants with the developed defensive building programme of the city and argue for a communal economy geared towards the common interest and probably co-administered by a collective leadership through a council or peer assembly. ${ }^{162}$ The economy of El Puig was based on cereal, which was presumably exchanged for salted fish, wine and, maybe, the occasional luxurious Greek pot. El Puig de la Nau flourished in the second half of the fifth century but like other settlements in the País Valenciano, it was abandoned peacefully around $400 \mathrm{BC}$, probably as a result of the depletion of natural resources or the political restructuring of the area. ${ }^{163}$

\section{V.2. Private display of old objects}

\section{V.2.1. Case 7: L'Orleyl (Vall d'Uixó, Castellón)}

159 I thank Marta Santos, Pere Castanyer, Elisa Hernández, Gabriel de Prados and Ferrán Codina, for granting me access to the material of the excavations from Ampurias and Ullastret in June 2019.

160 These observations are based on good quality photographs of the cup for which I am grateful to Arturo Oliver Fox, but unfortunately, I have not been able to inspect the object myself.

161 See note 55 supra. Ancient repairs are also usually taken as appreciation and/or value indexes, signalling the agency of the consumer. This might apply to many cases of mended vases, in particular to Athenian pottery, a luxury or semi-luxury product. Nevertheless, the equation 'repairs=value' is not always straightforward and I suspect that if more contextual information and use-wear analyses were generally available we would be able to tell, for example, if a given vase was mended after a long period of use by the owner (deposition context considerably later than the estimated manufacture date; use marks, unless it was mainly a display object) or if it might have arrived mended to the final user, i.e. pots shipped mended from Athens (entrepreneurial mending, as Susan Rotroff calls it, Rotroff (2011) 127-8) or, more likely, if retailers acquired and mended pots that had broken during transit. In this sense, the similarity of the breaks on two kraters by the Eucharides Painter found in the Valle Trebbe cemetery at Spina makes Elizabeth Langridge-Noti (2013) 68 and (2015) 179-80 wonder about the possibility of breakage on the journey over. This scenario would downplay the agency of the user, transferring the decision to repair to the producer or to the middlemen but would nevertheless point to the value of imported pottery, albeit of a different kind than in the first scenario envisaged above, with economic reasons possibly taking the lead.

162 Oliver and Gusi (1995) 263.

163 Oliver and Gusi (1995) 260-61. 
A remarkable case of curation of an old type Cástulo cup - mid-fifth century - occurs in a late fourth-century tomb from the necropolis of L'Orleyl discovered in 1972. ${ }^{164}$ The Cástulo cup (fig. 9) was found standing on a black-gloss bowl with incurving rim that covered a redfigure bell-krater/cinerary urn, all of them of Attic manufacture (figs 10 and 12). Two lead rolls with Iberian language were inside the krater and another one beneath its foot. They refer to a male named BODODAS, 165 very likely the deceased whose cremated bones rest inside the krater. A scale plate and five weights were also placed in the burial. ${ }^{166}$ Although there are difficulties in translating the Iberian language, the texts contained on the three lead rolls seem to be related to prays, offerings, praises, etc. ${ }^{167}$ These are not defixiones but could be working along the lines of the golden Orphic tablets and similar funerary texts. ${ }^{168}$ The remaining grave goods include 41 fragments of iron weaponry - remains of a falcate and a sword - , five of bronze, an anklebone and plaster or mortar, as well as fragments of bronze fibulae. ${ }^{169}$ The krater with which the cup is associated is a work by the Amazon Painter and its chronology has recently been revised by Sánchez, who dates it to $c a .320-300$ BC. 170 The new date is based on morphological and stylistic comparisons with the findings of the ceramic refuse deposit of the Amazon Painter's workshop discovered to the north of the Kerameikos and published by Norbert Eschbach for which a date around 312-311 BC was suggested. ${ }^{171}$ The krater from L'Orleyl was surely one of the last vases to arrive in the Iberian Peninsula and it is meaningful that it is paired precisely with a Cástulo cup of the old type, one of the earliest vases to arrive when the trade of Athenian pottery to Spain begins in the middle of the fifth century.

The identity of the deceased is not clear but his possible links with Orphic rituals as well as the commercial nature of his job have been suggested. ${ }^{172}$ The first possibility, i.e. that the person interred was an Orphic priest and/or initiate, is highly unlikely: there is no evidence whatsoever of Orphic communities in Iberia. ${ }^{173}$ The entire assemblage might be constructing identity for an elite merchant instead, hypothesis favoured by the experts on Iberian language. ${ }^{174}$ The scale and the weights strongly suggest this and the presence of metal objects

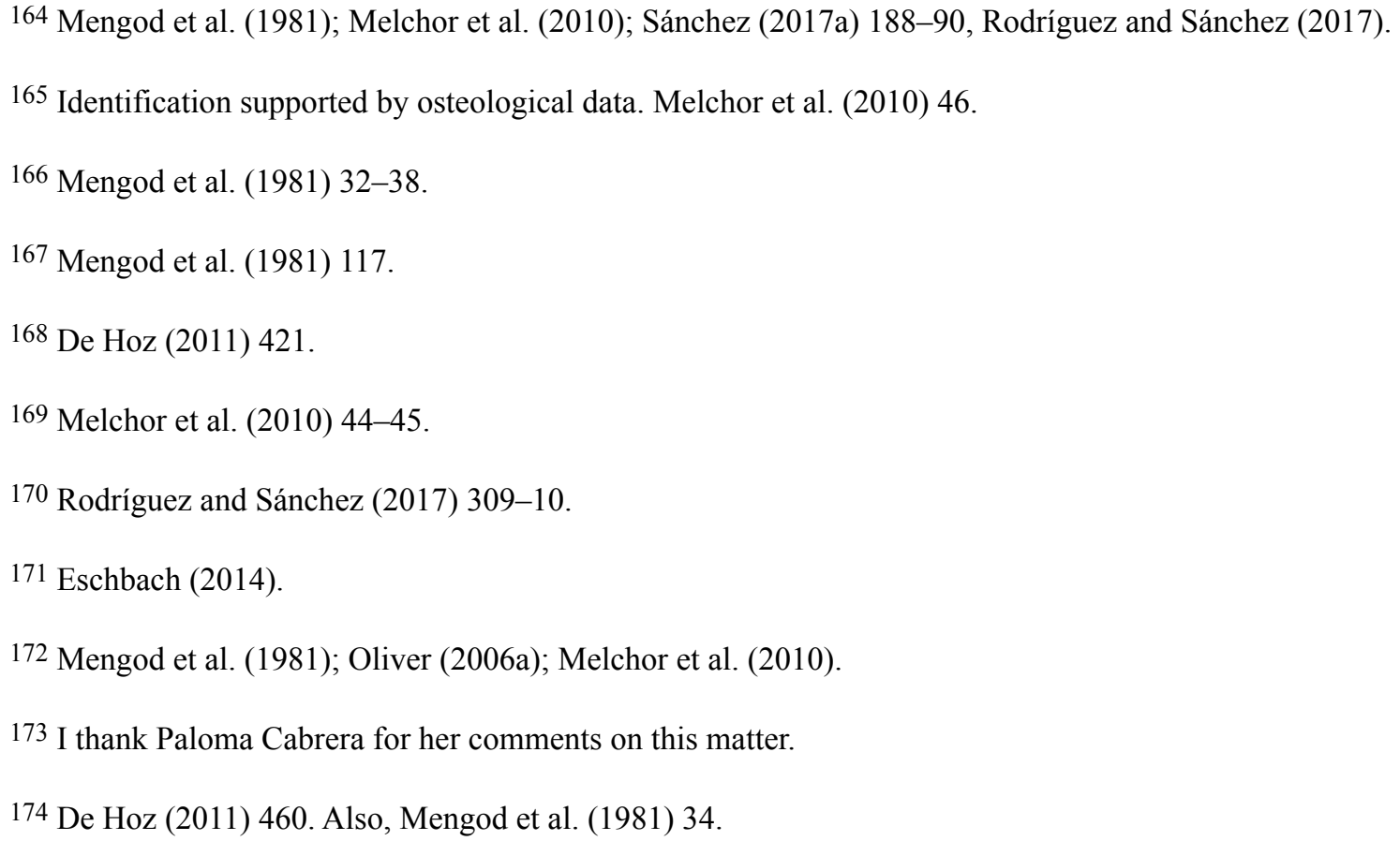


and written lead rolls communicate the image of a wealthy individual of an elevated social rank. The difficulties posed by the rolls are manifold; Javier De Hoz interprets them either as referring to the activities of the deceased, alongside the weights and scale, or as alluding to eschatological beliefs that, according to him, would be expressive of a certain degree of Hellenization acquired by merchants at this time. ${ }^{175}$ Regardless of the inappropriateness of the term 'Hellenization' here, the implied funerary ritual and material culture of the tomb, including exogenous elements, i.e. the Athenian pots, do speak of a well-connected individual, a travelled man who might indeed have got acquainted with southern-Italian eschatology through travel. ${ }^{176}$

\section{V.2.2. Case 8: Cástulo cup from tombs 149 of the necropolis of Tútugi (Galera, Granada)}

Tomb 149 is a simple rectangular pit located in sector III of the necropolis, the area of the 'ordinary people'. ${ }^{177}$ This sector was in use in the third century $\mathrm{BC}^{178}$ and concentrates the highest occurrence of 'antiques' of the whole necropolis. Tomb 146, of the second half of the first century BC included an Iberian funerary urn of the fourth-third centuries BC that still preserves five lead clamps. ${ }^{179}$ Likewise, the two urns from tomb 150 have been dated to the third century while the rest of the assemblage ranges from the first century BC to the first century AD. ${ }^{180}$ From what has been published, tomb 149 is the only burial in zone III to include an Attic pot: a Cástulo cup of the old type datable to the first half or towards the middle of the fifth century. ${ }^{181}$ The inventory of grave goods includes two ash-urns, implying that this was a double burial. Besides the urns with their lids, there were some five small Iberian vessels and a fibula of La Tène type, all dated to the mid-fourth century or later. ${ }^{182}$ The Cástulo cup is of the reserved type and the quality of the black gloss is quite good (fig. 11). The abundant wear marks inside the bowl betray its long history/intense use. It shows attrition of the ceramic surface, mainly radial and chordal abrasion in the form of linear scratches likely caused by tool use and five eroded patches. The scratches accord well with the marks left by eating utensils, i.e. cutting, a rather unexpected use for a cup. ${ }^{183}$

\footnotetext{
175 De Hoz (2011) 460.

176 I thank Mark Stansbury O’Donnell for this suggestion.

177 Cabré and Motos (1920) 51.

178 Rodríguez (2014) 249; Pereira et al. (2004) 133-63, fig. 88.

179 Pereira et al. (2004) 143.

180 Pereira et al. (2004) 157-61.
}

181 Madrid, Museo Arqueológico Nacional inv. no. 1979/70/GAL/T149/6. I thank Esperanza Manso for facilitating the access to this cup and to other Attic material from Iberian sites kept in the Archaeological Museum of Madrid.

182 Pereira et al. (2004) 155-57.

183 The expected type of attrition on cups and bowls are concentric marks caused by repetitive stirring. The marks on the Cástulo cup are not unlike the relatively long chordal and radial scratches produced by knives and/ or other cutting implements found on black gloss plates from central Italy, see Banducci (2014) figures 5 and 6 , but ours are thicker and show a higher degree of glaze loss. 
Nevertheless, use-wear analyses of Athenian vessels are virtually non-existent and because of the particular properties of the Athenian black-gloss it would be risky to transfer results of use-wear analysis on other wares to our products.

\section{Discussion}

The previous lines have presented two main types of depositions of older Athenian vases on the Iberian Peninsula according to the public or private nature of the depositional act and therefore the number of individuals who would have seen the object. Likewise, two divergent treatments of such vases have been mapped out according to the estimated length of time elapsed between manufacture and final deposition: intra- vs. inter-generational objects. Seven cases concerned instances of funerary curation and one, I will argue, was part of a ritual assemblage. It is now time to explore how and what such old vases might have communicated to a contemporary audience - and also to the modern scholar -, but first, we need to review the available theoretical models to understand and classify old objects in asynchronous assemblages from a functional viewpoint.

\section{VI.1. Terminology}

Keimélia is the name that occurs more often in publications addressing this phenomenon 184 but other terms, such as memory objects/objects of memory, biographical or entangled objects, old objects or heirlooms are also frequent. ${ }^{185}$ The word keimélia (sing. keimélion) occurs for the first time in Homer to refer to costly objects kept and cared for across time usually made of precious metals - that great chiefs possessed. These objects were laid up in store and occasionally gifted to others, often within the framework of Greek hospitality rituals (xenia) and of political relationships ${ }^{186}$. They are heavily biographical and entangled objects that become meaningful through their links to a series of owners who are united by their knowledge of the object's history. ${ }^{187}$ Keimélia are not commodities and their possession is not a product of trade but of gift-exchange among peers, i.e. aristocrats. When exchanged within the framework of the xenia rituals, they become material witnesses of ancestral guestfriendships that the descendants of the original parties must honour. 188 What matters is not the object itself, but its agency: the exclusive network of relationships that it embodies and to which the recipient of the keimelion is automatically incorporated. Related meanings of keimèlia in the ancient literary corpus are, according to Reiterman's research, those of inalienable possessions, remembrance/commemorative objects, rewards and objects invested with magical power/talismans. ${ }^{189}$

\footnotetext{
184 Guggisberg (2004); Reiterman (2014) and (2016); Fischer (1973).

185 Verger (2019b); Whitley (2013); Lillios (1999).

186 Hom. Il. VI, 46-51 and XXIII, 270, 616-24; Od. I, 312-18 and IV, 587-92 and 615-19.

187 Weiner in Reiterman (2016) 21.

188 Fischer (1973) 445.

189 Reiterman (2016) 20-23.
} 
Current scholarship uses the term in a less restrictive way, as 'objects with signs of ancient curation' 190 but due to its Homeric connotations, I will opt for a more neutral term, 'old objects', the equivalent to Guggisberg's 'Altstücke'191 and Kistler's 'archaika' ${ }^{192}$ I will avoid the term 'heirloom' for the description of the category because I understand heirlooms as a specific type of old objects, those that were passed down within the same family. ${ }^{193}$ The most comprehensive model to understand the functions of old objects in general in the ancient Mediterranean is Reiterman's $\mathrm{PhD},{ }^{194}$ preceded by Lillios' ethnographic study of the use of heirlooms in societies with hereditary rank. ${ }^{195}$ Very recently, Kistler's team's investigation of the use of old and antiqued objects in the indigenous settlement of Monte Iato (Sicily) ${ }^{196}$ stands out. Outside the Mediterranean area, we count the several valuable contributions to the study of old objects among late Hallstatt-early La Tène's cultures that offer many comparison points with the Iberian situation, ${ }^{197}$ as well as a recent edited volume comprising case studies of older objects in later contexts ranging from the Bronze Age through to the eighteenth century AD in Britain, Ireland and north-west Europe. ${ }^{198}$ Lastly, James Whitley's article on the archaeology of Homer's entangled objects also contains relevant insights for the present research. ${ }^{199}$

Reiterman distinguished several categories of old objects according to their nature and function: companion objects, mementoes, heirlooms, entangled objects, antiques and found objects. ${ }^{200}$ Her classification is sensitive to the multiple nuances of old objects in the archaeological record and is flexible enough to allow for communication between categories: an old object can acquire various successive roles as it ages and gets exchanged, an aspect that the present research also illuminates. While Lillios concentrates more on the public use of heirlooms sensu stricto as effective tools in social and political competitions, Reiterman allows for more personal meanings given the occurrence of these objects in quite intimate settings, such as a household or grave, and therefore their function might be more personal to the former owner of the object than public. Understanding the motivation behind a particular old object is not easy, though, being the 'mode of disposal [...] a key consideration of the

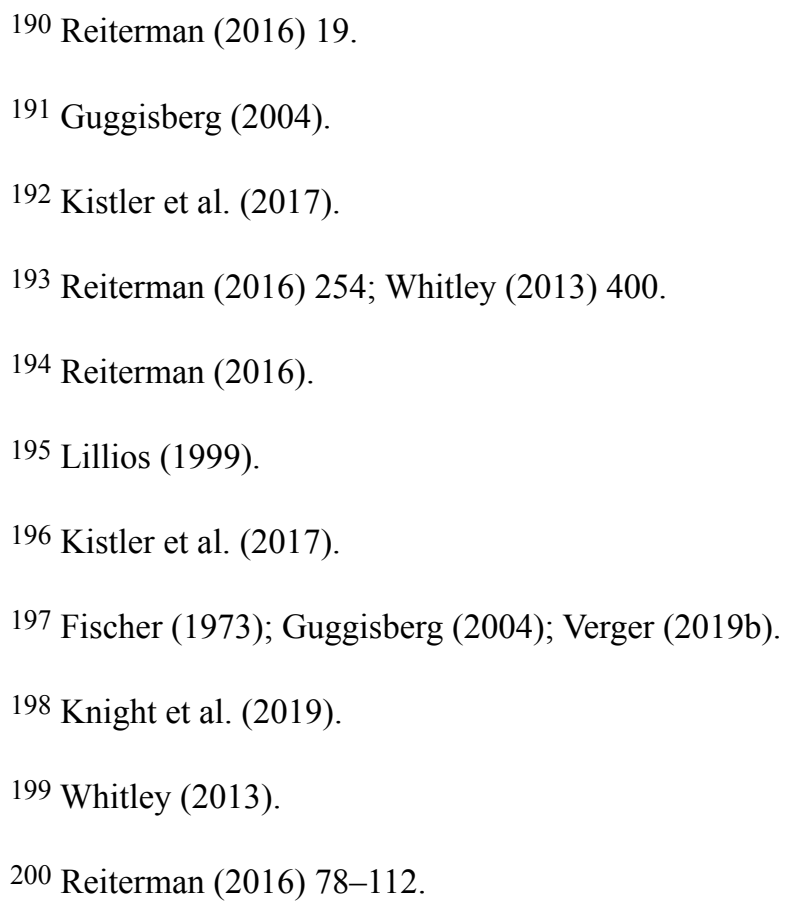


value of a keimélion at the time of its removal from circulation'. ${ }^{201}$ Indeed, it is most often only the archaeological context of the object, its position and relationship with the remaining items of the assemblage and what can be inferred about the social occasion when it was disposed of, what helps us choose between a public or private motivation behind the deposition.

\section{VI.2. Between private and public}

The older objects for which we privilege a political motivation behind their display and deposition are cases one to four. The consideration of a funeral assemblage as a case of public display might surprise but can be understood against the background of the significance of the funeral in Iberia - and other contemporary ancient societies - as a forum for display. ${ }^{202}$ The communal dimension of the tombs of the founders of the linage in Galera and their consideration as places of memory is beyond doubt: tomb 20 was initially a tomb-sanctuary where part of the interment ritual was performed, possibly revolving around the pouring figurine of Astarté (Lady of Galera), and was subsequently transformed into an open space with ritual function potentially linked to the cult of an hêrōs ktistēs or ancestor of the family group. ${ }^{203}$ It is not certain whether the grave goods were visible in the second phase or not but they were probably seen during the interment ritual of the first phase and during the performance of subsequent rituals when the tomb was reopened. A similar public display of the object is inferred for the red-figure cup from Castellones de Ceal, one of the more remarkable tombs of the necropolis, which contains evidence of - possibly - the celebration of a meal at the tomb and/or the ritual sacrifice of animals (sheep). ${ }^{204}$ The cup, as part of the personal objects of the deceased, was carefully deposited in the centre of the funerary chamber. An exposure to the public gaze may also be assumed for the two cups from La Albufereta disposed with numerous expensive exotic items in an impressive act of conspicuous consumption resulting in the votive deposit L127A. A similar scenario can be envisaged for the grave goods deposited in the tomb of the Iberian prince Iltirtitir, which suggest a complex multi-stage ritual. This extraordinary funerary chamber was surrounded by a sacred area with a space for ritual performances and one of the few libation channels attested in the Iberian world. ${ }^{205}$ According to the latest interpretations of the deposit of La Albufereta and the tomb of Piquía, ${ }^{206}$ a similar motivation may lie behind them: both can be understood as acts intended to legitimize the power of elite groups displaced from their seats of power as a result of processes of socio-political change in the wake of the turmoil generated by the Carthaginian presence in the area of La Albufereta and of the Second Punic War in the case of Piquía. Their interpretation as acts of re-foundation of linages is of

\footnotetext{
201 Reiterman (2016) 257.

202 On Iberian funerary rituals, see, e.g., Almagro-Gorbea (1993-1994); Pereira and Madrigal (1994); Izquierdo (2007); Sánchez and Gómez (2008) 75-83.

203 Rodríguez and Pérez (2013).

204 Chapa et al. (1991) 340.

205 Ruiz et. al. (1991) 359.

206 García (forthcoming); Ruiz et al. (2016) 373-74.
} 
paramount importance to understand the role of the old Athenian vases from the two assemblages.

So, the four examples noted above are linked by the great amount of energy expended in the interment ritual, tomb construction or votive act, which, I think, signifies a high level of social involvement and points to the high rank of the individuals who claim ownership of the act. This lets me interpret the significance of the objects involved in it in socio-political terms and understand them as material actors in the power dynamics characteristic of the period. Now the question follows of why old Athenian vases were used in these very distinctive occasions, what information they might have communicated to a contemporary audience and how they might have communicated it. At this point, the differentiation between intra- and inter-generational objects is, I think, meaningful. My main argument is that the Cástulo cups from a shallower chronological depth were being used to signal status/wealth, whereas the pieces from a long time ago were possibly used for active signalling.

\section{VI.3. Status/wealth signalling}

We have to understand the examples of Cástulo cups from Galera as part of the wider phenomenon outlined above (section IV) of the delayed deposition of the early type in the Iberian Peninsula. If, as it is my contention, the Cástulo cups of the old type did indeed arrive in the Peninsula by the mid-fifth century, ${ }^{207}$ possessing one of them - and this also applies to the type B cups and possibly to the cup from Castellones del Ceal - would mark the connectivity of their owners and their access to a restrictive market of foreign objects mediated by the colonial settlement of Ampurias. Indeed, Cabrera and Sánchez have noticed a marked drop in the flow of Greek imports to the interior of the Iberian Peninsula in the first half of the fifth century and up to around $430 \mathrm{BC}$ that would have resulted from various contingencies in the Mediterranean, Marsella's loss of commercial hegemony and Ampurias' slow take over. ${ }^{208}$ The access to Athenian pottery was limited and probably restricted to those with the right connections. The shortage of imported pots might have contributed to keep the vases in use for longer, a practice afforded by the sturdiness of the Cástulo cups. Evidence suggests that these vases were likely used in the life of their owners in the respective oppida and therefore the assumption that all Athenian pottery was bought for the tomb does not seem to be always true, ${ }^{209}$ at least in the fifth century.

Yet, it can be argued that the possession of one of these relatively rare pots might have worked as a socioeconomic indicator: a sign of belonging to the privileged few. Secondly, and closely related with the previous idea, the display of these 'exotica' might be working as a legitimizing tool: they materialize the access of their owners to overseas markets and are therefore a mark of a superior status which entitles, justifies and legitimizes the exertion of power over the ordinary people. The Athenian products must be understood within the context of the remaining items from the assemblages. As was mentioned above, these include objects of Orientalizing stock that efficiently perform a mnemonic bridging role, like the

\footnotetext{
207 Rodríguez (2019).

208 Cabrera and Sánchez (1994) 362. Compare numbers with Walsh (2004) 141-43.

209 On this regard, see also Adroher and Caballero (2010) 63.
} 
statuette of the Lady of Galera, a seventh- or eighth-century BC eastern manufacture that signals the stature of the deceased, probably a member of the royal family, and links them to a remote past. Likewise, the repurposed local vessels with polychromy on a white slip harking back to earlier Orientalising productions. In this context, the Cástulo cups do not work as ancestry markers, as I will argue our next group does. Much to the contrary, albeit old, they are a breath of fresh air signifying their owner's and his/her family's alignment with the latest Mediterranean fashions. Exposed to the public view during the funeral procedures, the assemblage of grave goods would demonstrate who the deceased - and their family were in relation to the others looking on from the distance.

One main argument to suggest that the late deposition of old type Cástulo cups was not connected to any particular ancestry claims is that they are not distinctive enough with respect to the all-black Cástulos to have been understood as 'antiques' by the ancient viewer. Whereas modern scholars equipped with comprehensive pottery typologies can indeed point to the long life of the old type when it appears in later contexts, the ancient Iberian was presumably not sensitive to the chronological implications of the slight glaze variations distinguishing both types. Old type Cástulos might communicate some sort of ancestry to the modern scholar and to their owners, but that was not their main function in their original context. There, I argue, their Athenian origin communicates connectivity and high social rank while their old age serves to punctuate these ideas further. Lastly, we cannot forget the relationship of this shape with the elite practice of wine consumption, ${ }^{210}$ ultimately linked to the development of an aristocratic society in search of signs to distinguish itself in life but also - and most importantly - in death.

\section{VI.4. Active signalling - ancestry}

The second set of case studies comprised vases from a much earlier time used, I argue, for active ancestry signalling. The activation of this role is dependent on the chronological distance between manufacture and deposition dates. Indeed, the real mnemonic potential of the old object is only unleashed when this chronological gap is long enough, as in the cases of Piquía and La Albufereta. In those contexts, Athenian vases might be working as mnemonic bridges that fulfil a very precise function: they help negotiate new identities and naturalize the new political situation by successfully rooting it in the tradition. Two questions will be explored in the following lines: the potential life-stories of the two sets of old vases and the ways they communicated ancestry.

The final deposition of the cups from La Albufereta and the kraters from Piquía happened some two hundred years and over three hundred years respectively after their manufacture in Athens. Where were they before that point? Reiterman considers that when there is a vast temporal and/or cultural gap between an object and its curators, we might be dealing with 'found objects', i.e. 'things deposited in the archaeological record for a substantial period before they came back into circulation', or antiques possibly acquired via a second-hand

\footnotetext{
210 On the cultural and social significance of feasting, especially in what concerns community-wide status competitions, see Dietler (2010) 75-88.
} 
market. ${ }^{211}$ This is particularly true of examples like the prehistoric arrowhead found at Pithekoussai and others she discusses. In those cases, it is highly unlikely that the original meaning of the object was preserved and therefore its later curators 'could inscribe new, invented meanings as they initiated another phase in the object's life'. ${ }^{212}$ They usually invest magical or divine qualities upon them. But despite the temporal gap, our pots from La Albufereta and Piquía do not fit this scenario: their deposition patterns point to a genuine intentionality that sets them apart from the randomness of the found object. I think that their pasts are not 'disconnected' 213 and that, as will be seen, a powerful emotional link connecting their original owners with their later curators might be grasped.

The question of the existence of a contemporary antiquities market was briefly explored and ruled out for the case of the kraters: had such a market existed, one would expect to find a higher number of similar asynchronous objects, ${ }^{214}$ and this also applies to the cups from La Albufereta. Rather, we need to assume that these objects were not in circulation at the time of deposition, which is also suggested by the good preservation of the added white on the kraters. Nevertheless, the problem remains of how those vases made it to the third and first centuries BC: were they kept in the storeroom of the prince's house for many generations? As Arturo Ruiz and his team pointed out, ${ }^{215}$ the Homeric poems provide parallels to the long treasuring of valuable objects (the storerooms of Odysseus' palace) ${ }^{216}$ but the archaeological record of the oppidum of Urgavo to which the necropolis of Piquía was associated precludes the storeroom hypothesis: habitation in this and other oppida of the lowlands of the Guadalquivir River has only been attested for the second and first centuries BC whereas the kraters date to the fourth century BC, the High Iberian period. At that time, activity focused on other urban centres to the south, like Ipolca (Porcuna) or Cerro de Villargordo. These large oppida were abandoned after the Second Punic War (218-201 BC) and the population moved back to the lowlands of the Guadalquivir to found new urban centres, like Urgavo. It is against this context that the extraordinary assemblage of Piquía can be understood: the oppidum of Urgavo was probably founded by the elites displaced from Cerro de Villargordo who used selected items from their ancestors' grave goods buried in their home oppida and presented them as family heirlooms in order to re-establish their lineage - and right to rule in the new settlement. 217

\footnotetext{
211 Reiterman (2016) 104-09 and pers. comm. 10 May 2017. For the definition of 'found objects', see her footnote 221 .

212 Reiterman (2016) 109.

213 Reiterman (2016) 102.

214 Ruiz et al. (2016) 369-70.

215 Ruiz et al. (2016) 373-74.

216 Also sanctuaries provide numerous examples of the phenomenon of object 'treasurization', in particular of cuirasses. See Graells (2016).
}

217 Ruiz et al. (2016) 374. 
Another point regarding the origin of the kraters can be made if we look at their iconography. They are decorated with images of weddings, banquets and apotheosis (fig. 5) and have been understood by Olmos and Rueda to shape a coherent iconographical programme revolving around the idea of marriage and lineage. ${ }^{218}$ Whereas I disagree on the identification of some scenes with particular mythical accounts like the krater with a feminine bath as being Helen's bath, the fragmentary krater bearing the image of a rython as representing a ritual situation involving Dionysos and the wedding scene as being that of Paris and Helen or the understanding of some of the vases as commissions, I do think that an overarching theme might nevertheless be understood where marriage, feasting and apotheosis feature prominently. If such an overarching theme actually exists, we might be able to speak about a conscious choice behind the final deposition of these vases in Iltirtiitir's tomb. Indeed, while bell-kraters (and stemless cups) were the usual Athenian imports in fourth century Iberian tombs of the High Andalusia, a concentration of six or seven kraters and a cup in a single burial was exceptional. ${ }^{219}$ To my mind, the iconography, painters and shapes represented (and not) in Piquía evidence that several earlier tombs were explored and only selected items were taken: those which met the particular agenda of Iltirtiitir's family and the message they wanted to communicate. ${ }^{220}$ This hypothesis is appealing but a cautionary note is in order. A selection process such as the one we might envision in Piquía would necessarily imply at least a basic understanding of Athenian imagery by first-century Iberians, which, these days, looks to me unlikely. Were that the case, the assemblage of Greek pottery from Piquía would open the field to explore the appropriation of Athenian iconography in Iberia long after Athenian images went out of fashion.

A similar act of reclamation of the past seems to have taken place in La Albufereta. ${ }^{221}$ It was mentioned before that stemmed red-figure cups are rare outside Ampurias and that they could have functioned as personal gifts to strengthen trade relationships. The painter of the cups from La Albufereta - Painter of London E 106 - is exclusive to Ampurias ${ }^{222}$ and the presence of two of his products south of the colony must be credited to the Empuritan trade,

218 For an iconographic study of the assemblage, see Rueda and Olmos (2016). For the attributions of the kraters, see Sánchez (2014).

219 The most accomplished fourth-century Iberian tombs with Athenian pottery contained an average of three kraters with the exception of tomb 176 of Baza, which included five red-figure kraters and black-gloss pottery.

220 Similar hints at a purposeful choice have also be suggested for the curated Athenian pottery of La Albufereta, see Olmos (2000-2001) 363; García (2017) 218-19.

221 We need to draw attention here to similar reclamation acts attested in other Iberian territories. This is the case of the extraordinary warrior tombs from the necropolis of Pedrera (Vallfogona de Balaguer, Térmens, Lérida) that have been thoroughly investigated by Graells. These are the tombs of two mercenaries from the Iberian people of the Ilergetes (northeast of the Peninsula) who re-occupied an old sixth-century BC abandoned necropolis in order to trumpet their family lineage and right to rule by making use of the shared past of the community and their aristocratic status, maybe achieved after amassing wealth, prestige and honour as mercenaries in the Mediterranean. See Graells (2008) and (2014) 177. See also, in our area, the paradigmatic case of Cerrillo Blanco, Porcuna (Jaén), where an extraordinary sculptural group was set up in the mid-fifth century bordering an Orientalizing (seventh century) tumulus as a reclamation of the past. Meaningfully, this group was destroyed shortly after its erection by the antagonist group that deposed the heirs of those interred in the earlier tumulus. See Negueruela (1990); García (2012); Ruiz and Molinos (2015).

222 There are six examples in Ampurias. See Miró (2006) nos. 328-33. 
particularly strong in the last quarter of the fifth century BC. Due to the shorter gap between manufacture and deposition dates in this case, a scenario involving the re-opening of ancestors' tombs might be unnecessary and a continuous curation could be envisaged. Both cups might have been kept as heirlooms aboveground and were later used in a similar vein to the Piquía kraters: when the ruling family of El Tossal de les Basses settled down in El Tossal de Manises, they might have employed the cups to their legitimizing claims to social-political authority. Unlike found objects of a remote past and similarly to the kraters from Piquía, we can see their function as a continuum: they have retained their prior associations even when exchanged and moved through time. If they had followed the normal biography of other pots of their kind in the Iberian Peninsula, they would have been deposited as grave goods in a tomb of a prominent Iberian in the fifth or fourth century BC after a variable period of use in the settlement. They would have signalled off their owner in that context. But our cups followed a different path: they were likely kept within the family and were curated continuously for two centuries. Why and how? We just don't know but what interests us here is that in the fifth century, like in the third, Athenian pottery would have been used in a similar way: as diacritical sign to emphasize social stratification and lineage, the shape and provenance of the vases being probably the main actors in the communication process. The difference between the two periods is only qualitative: if earlier on the social stratification factor was possibly more powerful, in the third century, it seems to me that lineage is being brought to the front. Indeed, the effectiveness and legitimizing potential of an old Athenian pot in third-century BC Iberia is leveraged precisely when used 'as the ancestors would' in that past 'golden age': as grave goods or in acts of conspicuous consumption. Even if we reject the hypothesis of a continuous curation within the family, and therefore, the status of the vases as heirlooms sensu stricto, and envisage a different access route to them, it still seems to me that they are indeed presented as such. These intended or appropriated heirlooms, as I would call them, would form a new category of old objects indicative of an informed and highly sophisticated use of material culture by later generations. ${ }^{223}$ More examples of these can surely be found once we are alert of the category.

Our findings about the use of heirlooms as markers of hereditary rank or ancestry within the Iberian society agrees well with Lillios' modelling of the circulation of such objects in societies with hereditary rank. 224 She understands the phenomenon as the relationship of two variables, achieved and ascribed status, that is, status based on one's own achievements vs. status based on appearance or inheritance. It is precisely in times of instability and competition between both systems that heirlooms acquire power and visibility. Nevertheless, the use of heirlooms observed in our Iberian case studies seems to go against Lillios' main conclusion that 'only when heirlooms lose their meaning as emblems of hereditary rank [...] they enter into the archaeological record, in a burial or a refuse deposit' ${ }^{225}$ Her claim is that unstable systems would cause a more intense circulation and display, rather than disposal, of heirlooms over longer periods of time. The cases of Piquía and La Albufereta point, as seen

223 Instances of fictive kinship constructions in the mortuary realm are also known, for example, in Mesoamerican archaeology. See one such case in Van Dyke (2019) 213.

224 Lillios (1999).

225 Lillios (1999) 257. 
above, in the opposite direction: by giving up these objects the descendants are not losing their own claim to the past as a working part of their identity in the present but are, on the contrary, using them to reify that identity, to signal inherited social difference - either actual or appropriated - in a rather public setting. In the context of the marked philhellenism of the first century $\mathrm{BC}$, the Athenian kraters work like the Orientalizing objects centuries earlier, i.e. they signal the roots and the prestige of the past, whereas the Roman material is, as the Greek imports before, the sign of the new times. 226

\section{VI.5. Personal Motives}

Similar power dynamics to those just discussed above do not seem to be present behind the use of a centenary old Cástulo cup in the tomb from L'Orleyl and in number 149 of Galera. The characteristics of the burials and the remaining grave goods do not allow for the identification of the deceased as a member of the ruling political elite. Likewise, whereas a degree of public exposure can probably be assumed for most Iberian burials - not least because of the pre-eminence of cremation over inhumation -, the character of both burials seems to be more private.

Such is the case of tomb 149 from Galera. An interpretation privileging power as a motivation factor is here simply not possible. As mentioned above, this is a humble burial both from the architectural point of view and from its furnishings and is located among other unremarkable burials in the poorest sector (III) of the necropolis. Rodríguez Ariza and her team have distinguished some five to seven groupings of tombs in the necropolis that might correspond with a similar number of family or clients groups from the oppidum of Tútugi.227 But this sector has not been as well explored as zones I and II so any suggestion about the identity of the deceased and the spatial organization of the burials is highly hypothetical. There is no evidence to argue for a political use of the cup in this context, so we would need to speculate about a potential emotional attachment of the couple interred to the object. Indeed, cups, like any other objects intended for individual use, can be envisaged developing intense attachments from their owners, being used and curated for extended periods of time and maybe handed down from a particular person in a line.

Such line transmission could also be argued for the Cástulo cup from L'Orleyl but the stature of the deceased as constructed by the grave goods sets him apart from the couple above. It has been pointed out that the presence of early material in third-century and later contexts in the area to the north of L'Orleyl should be understood as the result of a redistribution process of luxury ware after the established routes through which these items reached the Peninsula had disappeared and before the black-gloss products from the central Mediterranean and the gulf of Lion came to dominate the markets. 228 While supply and demand factors must always be taken into account and availability or lack thereof might apply to some cases of prolonged use in the north-eastern area of the Peninsula to which Gracia refers, the case of L'Orleyl

\footnotetext{
226 Ruiz et al. (2016) 374. Ricardo Olmos (2010) 59 understands the first century BC philhellenic wave in the Iberian Peninsula as a reaction against the Roman colonizer and mark of indigenism.

227 Rodríguez (2014) 252.

228 Gracia (2003) 57.
} 
seems different. The tomb included two brand-new Athenian items - krater and bowl with incurving rim - that do not show any signs of use other than their post-depositional fragmentation. The grave goods, including metal weaponry, do not convey an image of limited economic means at all. It looks like the mortuary assemblage of a prominent person of the community. Were this man a merchant, as advanced before, it would not be difficult to understand the presence of a curated Athenian cup with two new brand vases as expressive of his - and maybe his family's - (long-term) involvement in overseas markets.

Besides being, maybe, a treasured heirloom with some signalling potential, the iconography of the krater-cinerary urn associated with the cup suggests a possible referential framework to which the set might be alluding. The krater bears a representation of a Gryphomachy (fig. 12), a popular funerary theme in the Iberian Peninsula invested with apotropaic overtones. Juliette de la Genière called the attention to potential links between this funerary use of the krater among the communities of Italy, Sicily and Andalusia with salvation religions. ${ }^{229}$ Indeed, the orgiastic elements in Iberian iconography were explored by Olmos in the past. ${ }^{230}$ Evidence from funerary assemblages from Italy and Sicily, together with our material from Spain, suggests that those interred in that way were people of certain importance and De la Genière thinks that in places where this burials of this type appear together, like in Camarina, Gela or Selinunte, a religious dimension added to the social distinction factor can be grasped. ${ }^{231}$ The iconography of the kraters, usually pursuit scenes and warriors departing in Italy, and Amazonomachies, banquets and Dionysiac scenes in Spain, may also point in that direction. The egg-shells that appear inside the kraters in Selinunte, the images of winged beings performing libations like on the krater from Galera and a parallel one from Selinunte, the iconographical prominence of figures such as Heracles, Orpheus and specially Dionysos, or instances like the impressive metal volute-krater from the tomb B from Derveni - a keimelion on its own ${ }^{232}$ - and the Orphic papyrus found in tomb A indicate that the deceased so buried might have been initiates of or at least point to the new eschatological beliefs and the hope of the potential heroization of the dead that were taking root in the fourth century BC. 233

Without positing an identification of the deceased with an initiate in the Orphism, for which there is no evidence, the cup might indeed be understood as a reference to a funerary ritual with a libation of wine expressive of the post-mortem happiness that the deceased would enjoy in the netherworld, also alluded to by the cinerary krater. ${ }^{234}$ Funerary libations with

\footnotetext{
229 De la Genière (1987).

230 Olmos (1990).

231 De la Genière (1987) 275.

232 Barr-Sharrar (2008) 25-27, 180-81.

233 De la Genière (1987) 276-77.

234 Indeed, as Paloma Cabrera kindly points out to me, these are signs of the new eschatological beliefs mentioned above that revolve around the happiness that awaits the deceased in the underworld and that are common to the wide Mediterranean area at the time.
} 
wine were apparently as common among the Iberians as they were in the Greek world. The set krater and cup in a tomb is sometimes too literally understood as an allusion to the symposium but as in the case of most other cups under analysis in this article, the focus seems to be more on libation than on the consumption of wine in a banquet setting. The performance of funerary libations has been attested for Cabezo Lucero (Alicante), for example. Rouillard notes the presence of broken and burnt drinking vases on top of primary cremations, what indicates the performance of libations and the tossing of the vases in the pit at the end of the process, when the ashes were still hot. There is even a case of a lekythos used for that same aim that nicely exemplifies the repurposing of Athenian vases in an Iberian context. ${ }^{235}$ Cabezo Lucero also provides examples of curated Cástulo cups and the deposition pattern of one of them, from the primary cremation of Point 21-22, is similar to L'Orleyl cup, i.e. it was carefully placed on top of the assemblage, which also included metal weaponry. This cremation from Cabezo Lucero belongs to a notable individual as well, as can be inferred from the multiple and varied grave goods, including what is described as a fragment of 'archaizing pottery'. ${ }^{236}$

Both case studies discussed above exemplify the existence of more private motivations to the late deposition of Athenian cups in Iberia, including emotional attachment to the object and religious observance. At the same time, it is right to observe that even when more personal attitudes can be spotted, the signalling potential inherent to all Athenian pottery in Iberia, especially in what concerns connectivity and wealth, is still working in the background.

\section{VI.6. Curation of a ritual implement?}

The case of the Penthesilea Painter's cup from El Puig de la Nau differs from the others in that it is the only instance of non-funerary curation in the sample. The fact that our cup remained in the settlement - interred in pieces along its main street - when the population left is significant and, I think, points to its previous function. It indicates that instead of being one individual's own treasured possession, it was probably used in a more communal setting, plausibly a ritual act involving fire, e.g. a libation and a sacrifice with the cooking of meat afterwards, since some of the fragments are burnt. ${ }^{237}$ As a ritual implement, and like any objects dedicated or used in a sanctuary context, it would not have seemed appropriate to remove the cup from the place.

What type of ritual might this have been? Because of the exclusivity of the object, we might think of either a foundation or an abandonment ritual performed by the ruling elites of El Puig who were benefiting from the exchange of the cereal surplus - this particular cup surely arrived from Ampurias, maybe after a successful transaction -. It is precisely in the phase $\mathrm{V}$ of the settlement (450-400 BC) when the excavators have identified the beginning of ritual activity in the form of infant primary and secondary inhumations under the houses and the

\footnotetext{
235 Aranegui et al. (1993) 49-51; Rouillard (2010) 118.

236 Aranegui et al. (1993) 178.

237 I thank Ann Steiner for this suggestion.
} 
sacrifice of goats/sheep. ${ }^{238}$ If we assume that repairs usually signal an extended use-life, we are inclined to conclude about a 'farewell' ritual at the end of the fifth century when the settlement was peacefully abandoned.239 Indeed, the cup can be dated to around $460 \mathrm{BC}$ on stylistic grounds but appears in a context of the second half of the century. Putting the best pot that ever arrived at the settlement - and that was curated for a couple of generations - to a communal use surely served as a display of range status and elite authority too.

The possible ritual use of the cup from Benicarló brings to mind a type B cup from the Etruscan sanctuary at Poggio Colla that has been studied by Ann Steiner. ${ }^{240}$ It was found broken, but relatively complete, in one of the deposits marking the transition from the Temple I to the subsequent structure. Rather than a commensal shape, this cup, like probably ours, might have been used for ritual libations. Significantly, substantial proportions of both cups are preserved but not the complete shape. Steiner has wondered about a potential intentionality behind the partial preservation of the cup at Poggio Colla, ${ }^{241}$ a practice that is widely attested - and more obvious - in Etruria for other classes of material like stone or bronze. Similarly, Carmen Rueda 242 thinks that a large fragment of a red-figure krater with remains of sulphur discovered in the sanctuary of Puente Tablas, Jaén, ${ }^{243}$ was also intentionally left in the space before the caves when these were sealed. The cup from El Puig adds to these examples. As such, all these fragments could additionally be considered mementoes, i.e., as Steiner puts it, they would be 'intentional records of ritual', carrying with them 'the memory of the specific ritual action of libation'. 244

The partial preservation of material culture is a fascinating but understudied phenomenon with great potential to illuminate personal attitudes to and idiosyncratic uses of objects. Scholars of antiquity are fully aware that their objects of study, from material culture to literature, usually survive in fragments, and even when complete, they are regarded as fragments of a broader cultural context. Nevertheless, not so much attention has been paid to objects that already in ancient times were used in a fragmentary state, maybe with the exception of fragmented votive offerings - body parts - in sanctuaries. Intentional fragments are heavily entangled objects in which the agency of the human/s who acted on them and on which the once complete object simultaneously acted manifests itself at the highest degree. Only very recently has modern scholarship started to look at fragmentation in the ancient world from a theoretical point of view while also investigating individual case studies from

238 Oliver and Gusi (1995) 259; Oliver and Gómez (1989) 54-56; Oliver (2006b) 209-20.

239 Olmos and Oliver think of a foundational rite instead, see Oliver (2006b) 220.

240 I would like to thank Ann Steiner for making the manuscript of her article available to me before publication.

241 Steiner (in press).

242 Personal communication.

243 Ruiz et al. (2015) 104-5.

244 Steiner (in press). 
various disciplines. ${ }^{245}$ Among them, Stéphane Verger's study of lots of fragmentary bronze objects in the Iron Age western Mediterranean is an excellent example of the complexity and potential of the topic. 246 The use of intentional fragments of Athenian pottery in the Iberian Peninsula is attested in various contexts. The main examples are the trimmed tondi of cups and bowls occurring in tombs, in votive contexts, and even in the shipwreck of El Sec. The cup from Benicarló and the krater from Puente Tablas are probably not intentional fragments but do illustrate a particular use of fragmented material culture, i.e. its partial preservation, in Iberia.

\section{To conclude}

When seen against the background of the funerary assemblages and mortuary structures to which they belong, it is suggestive to understand the use of old Athenian pots in the examples discussed above as contributing to mark off the significance of the person interred, signalling his/her social status and relevance, as well as the ancestry of his/her lineage. The extent to which any of these aspects comes to the fore varies according to the socio-political situation in Iberia at the time.

Older Athenian pots were potentially used and can be understood in various ways in different moments of the development of the Iberian culture. In the tombs of the late fifth and early fourth century BC they are emblematic of economic success, social affiliations, and political rank. Expressive of one's own connections, they demonstrate who the dead were in relation to others. Although our research and reassessment of the chronology of the Cástulo cups evidences their relatively extended lives before their funerary deposition in the examples investigated, these curated cups do not seem to have been primarily used as ancestry markers but are, paradoxically, presented as the new element that attests to the connectivity and exclusive status of the deceased. They make a good pair with the remaining objects of their respective funerary assemblages, in particular, those in the Orientalizing tradition. Later on, the ancestry marker aspect becomes more relevant in connection with the Athenian vases. Turned into symbols of ancestry and elite status, they are used to legitimize claims to sociopolitical and/or religious authority by bringing back the group or individual's past (either actual or intended) into the present. Older vases, on the other hand, are not only used in the political arena and personal motivations and emotional attachment to the object are also contributing factors to their late deposition. Whether strict heirlooms - i.e. objects passed on within the family to descendants - or more general entangled objects - i.e. circulated and exchanged between elites or non-kin or even appropriated by some purported descendants -, curated Athenian vases, like Athenian vases in general, were smartly used and coveted as one of the primary means of negotiating social identity in ancient Iberia.

\section{Bibliography}

Adroher, A.M. and Caballero, A. (2010) 'El contexto de la Dama en el territorio de Basti', in T. Chapa and I. Izquierdo (eds), La Dama de Baza. Un viaje femenino al Más Allá (Madrid) 57-73

\footnotetext{
245 Dan et al. (2019). I thank Stéphane Verger for calling my attention to this publication.

246 Verger (2019a).
} 
Alcock, S. (2002) Archaeologies of the Greek Past: Landscape, Monuments and Memories (Cambridge)

Alfieri, N. (1959) 'Dalle necropoli di Spina: Grande kylix del pittore di Pentesilea con ciclo teseico', Rivista dell'Istituto nazionale d'archeologia e storia dell'arte 8, 59-110

Almagro-Gorbea, M. (1993-1994) 'Ritos y cultos funerarios en el mundo ibérico', AnMurcia 9-10, 107-33

Almagro-Gorbea, M. (2009a) 'El kylix de figuras rojas arcaicas de Pozo Moro (Albacete)', Quaderns de Prehistòria i Arqueologia de Castelló 27, 63-81

Almagro-Gorbea, M. (2009b) 'La diosa de Galera. Fuente de aceite perfumado', ArchEspArq $82,7-30$

Almagro-Gorbea, M., Lorrio, A., Mederos, A. and Torres, M. (2011-12) 'El mito de Telepinu y el altar primordial en forma de piel de toro', CuPAUAM 37-38, 241-62

Andronikos, M. (1984) Vergina: the Royal Tombs and the Ancient City (Athens)

Antonaccio, C. (1994) 'Contesting the past: hero cult, tomb cult, and epic in early Greece', AJA 98.3, 389-410

Aquilué, X. and Cabrera, P. (eds) (2012) Iberia Graeca. El legado arqueológico griego en la Península Ibérica (Girona)

Aquilué, X., Cabrera, P. and Orfila, M. (eds) (2017) Homenaje a Glòria Trias Rubiés. Cerámicas griegas de la Península Ibérica: cincuenta años después (1967-2017) (Girona)

Arafat, K. and Morgan, C. (1994) 'Athens, Etruria and the Heuneburg: mutual misconceptions in the study of Greek-Barbarian relations', in I. Morris (ed.), Classical Greece: Ancient Histories and Modern Archaeologies (Cambridge) 108-34

Aranegui, C. (2012) Los iberos ayer y hoy. Arqueología y culturas (Madrid)

Aranegui, C., Jodin, A., Llobregat, E., Rouillard, P. and Uroz, J. (1993) La nécropole ibérique de Cabezo Lucero. Guardamar del Segura, Alicante, Collection de la Casa de Velázquez (Madrid and Alicante)

Arribas, A., Trías, G., Cerdá, D. and de Hoz, J. (1987) El barco de El Sec (Calvia, Mallorca). Análisis de los materiales (Mallorca)

Assmann, J. (1995) 'Collective memory and cultural identity', New German Critique 65, $125-33$

Aubet, M.E. (2005) 'El "Orientalizante": un fenómeno de contacto entre sociedades desiguales', Anejos de ArchEspArq XXXV, 117-28

Aubet, M.E. (2009) Tiro y las colonias fenicias de occidente (Barcelona)

Aurigny, H. (2016) 'Sicilian and Italic votive objects in the Panhellenic sanctuary of Delphi', in H. Baitinger (ed.), Materielle Kultur und Identität im Spannungsfeld zwischen Mediterraner Welt und Mitteleuropa (Mainz) 161-74

Baitinger, H. (2011) Waffenweihungen in griechischen Heiligtümern (Mainz)

Banducci, L.M. (2014) 'Function and use of Roman pottery: a quantitative method for assesing use-wear', JMA 27.2, 187-210

Barr-Sharrar, B. (2008) The Derveni Krater. Masterpiece of Classical Greek Metalwork (Princeton)

Bellelli, V. (1995) “"Anomalie pompeiane", Prospettiva 77, 2-15

Bentz, M. and Kästner, U. (2007) Konservieren oder Restaurieren: die Restaurierung griechischer Vasen von der Antike bis heute (Munich) 
Bielfeldt, R. (2014) Ding und Mensch in der Antike. Gegenwart und Vergegenwärtigung (Heidelberg)

Boardman, J. (2002) The Archaeology of Nostalgia. How the Greeks Re-Created their Mythical Past (London).

Bonet, H. (1995) El Tosal de Sant Miquel de Llíria. La antigua Edeta y su territorio (Valencia)

Bonet, H. and Mata, C. (2001) El Puntal dels Llops: un fortín edetano (Valencia)

Bradley, R. (2002) The Past in Prehistoric Societies (London)

Cabré, J. and Motos, F. (1920) La necrópolis ibérica de Tútugi, Galera, Provincia de Granada. Memoria de las excavaciones practicadas en la campaña de 1918, Junta Superior de Excavaciones y Antigüedades (Madrid)

Cabrera, P. and Sánchez, C. (1994) 'Importaciones griegas en el sur de la Meseta', Huelva arqueológica $13.1,355-76$

Celestino, S. and López, C. (2016) Tartessos and the Phoenicians in Iberia (Oxford)

Chapa, T. (2004) 'La iconografía de la Necrópolis de Galera: a propósito de la caja cineraria de la tumba 76', in J. Pereira, T. Chapa and A. Madrigal (eds), La necrópolis ibérica de Galera (Granada): la colección del Museo Arqueológico Nacional (Madrid) 23954

Chapa, T., Madrigal, A. and Pereira, J. (1990) 'La cámara funeraria de Los Castellones de Céal (Hinojares, Jaén)', Verdolay. Revista del Museo de Murcia 2, 81-86

Chapa, T., Pereira, J., Madrigal, A. and López, M.T. (1991) 'La sepultura 11/145 de la necrópolis ibérica de los Castellones de Ceal (Hinojares, Jaén)', Trabajos de prehistoria 48, 333-48

Chapa, T., Pereira, J., Madrigal, A. and Mayoral, V. (1998) La necrópolis ibérica de los Castellones de Céal (Hinojares, Jaén) (Sevilla)

Connerton, P. (1986) How Societies Remember (Cambridge)

Connerton, P. (2006) 'Cultural memory', in C. Tilley, W. Keane, S. Küchler, M. Rowlands and P. Spyer (eds), Handbook of Material Culture (London) 315-24

Connerton, P. (2009) How Modernity Forgets (Cambridge)

Cruz, M., García, L. and Gilman, A. (eds) (2013) The Prehistory of Iberia. Debating Early Social Stratification and the State (London)

Dan, A., Briquel, D., Gruel, K. and Verger, S. (2019) 'Les concepts en sciences de l'Antiquité: mode d'emploi. Chronique 2019 - Fragments et fragmentation', Dialogues d'histoire ancienne 45.1, 207-90

Dávila, C. (2016) Evolución de la conservación-restauración en el Museo Arqueológico Nacional: Análisis histórico y técnico de los vasos áticos de figuras negras (Ph.D. Diss, UAM)

De Hoz, J. (2011) Historia lingüistica de la Península Ibérica en la Antigüedad. II. El mundo ibérico prerromano y la indoeuropeización (Madrid).

De la Genière, J. (1987) 'Des usages du cratère', $R E ́ A$ 89.3-4, 271-82

Dietler, M. (2010) Archaeologies of Colonialism: Consumption, Entanglement and Violence in Ancient Mediterranean France (Berkeley)

Dietler, M. and López, C. (2009) Colonial Encounters in Ancient Iberia: Phoenician, Greek, and Indigenous Relations (Chicago)

Domínguez, A. (2017) 'Cincuenta años de investigaciones sobre las cerámicas griegas de la península Ibérica (1967-2017)', in X. Aquilué, P. Cabrera and M. Orfila (eds), 
Homenaje a Glòria Trias Rubiés. Cerámicas griegas de la Península Ibérica: cincuenta años después (1967-2017) (Girona) 44-59

Domínguez, A. and Sánchez, C. (2001) Greek Pottery from the Iberian Peninsula. Archaic and Classical Periods (Leiden, Boston and Cologne)

Dooijies, R. and Nieuwenhuyse, O.P. (2007) 'Ancient repairs: techniques and social meaning', in M. Benz and U. Kästner (eds), Konservieren oder Restaurieren. Die Restaurierung griechischer Vasen von der Antike bis heute (Munich) 17-22

Dooijies, R. and Nieuwenhuyse, O.P. (2009) 'Ancient repairs in archaeological research: a near eastern perspective', in J. Ambers, C. Higgitt, L. Harrison, and D. Saunders (eds), Holding It All Together: Ancient and Modern Approaches to Joining, Repair and Consolidation (London) 8-12

Elston, M. (1990) 'Ancient repairs of Greek vases in the J. Paul Getty Museum', GettyMusJ $18,53-68$

Escacena, J.L. and Amores, F. (2011) 'Revestidos como Dios manda. El tesoro del Carambolo como ajuar de consagración', SPAL: Revista de prehistoria y arqueología de la Universidad de Sevilla 20, 107-42

Escacena, J.L., Fernández, A. and Rodríguez. A. (2007) 'Sobre el Carambolo: un híppos sagrado del santuario IV y su contexto arqueológico', Archivo Español de Arqueología 80, 5-28

Eschbach, N. (2014) 'Athenian vases for whom? A new workshop of the late 4th century in the Athenian Kerameikos', Metis 12, 99-118

Evans, J. and Millett, M. (1992) 'Residuality Revisited', OJA 11.2, 225-40

Fernández, A. and Rodríguez, A. (2005) 'El complejo monumental del Carambolo Alto, Camas (Sevilla). Un santuario orientalizante en la paleodesembocadura del Guadalquivir', Trabajos de Prehistoria 62.1, 111-38

Fischer, F. (1973) 'KEIMHAIA. Bemerkungen zur kulturgeschichtlichen Interpretatio des sogenannten Südimports in der späten Hallstatt- und frühen Latène-Kultur des westlichen Mitteleuropa', Germania 51, 436-59

Frankenstein, S. and Rowlands, M.J. (1978) 'The internal structure and regional context of early Iron Age society in south-western Germany', BIALond 15, 73-112

García, J. (2012) ¿¿Y qué fue de la estatua del abuelo? La reutilización de la escultura ibérica', in J.M. Aldea, P. Ortega, I. Pérez and M.R. de Soto (eds), Historia, Identidad y Alteridad. Actas del III Congreso Interdisciplinar de Jóvenes Historiadores (Salamanca) 279-303

García, J. (2017) 'Vasos griegos en la necrópolis de la Albufereta (Alicante): signos helenos para discursos contestanos', in X. Aquilué, P. Cabrera and M. Orfila (eds), Homenaje a Glòria Trias Rubiés. Cerámicas griegas de la Península Ibérica: cincuenta años después (1967-2017) (Barcelona) 213-20

García, J. (forthcoming) 'Domeñando el tiempo y el espacio. La instrumentalización del rito y la memoria social en la necrópolis de La Albufereta'

García, J.M. (1999) 'Un aspecto poco tratado en las necrópolis ibéricas. La perduración de objetos en los ajuares: el caso de Murcia', in M.A. Valero (ed.), Primeras Jornadas de Arqueología Ibérica en Castilla-La Mancha (Toledo) 169-79

Gell, A. (1997) Art and Agency. An Anthropological Theory (Oxford) 
Giudobaldi, F., Pavolini, C. and Pergola, P. (1998) I materiali residui nello scavo archeologico: testi preliminari e Atti della tavola rotonda organizzata dall'École française de Rome (Rome)

González, F., Serrano, L., Llompart, J., García, M., Ramón, J., Domínguez, A. and Montaño, A. (2017) 'Archaeological finds in the deepest anthropogenic stratum at 3 Concepción Street in the city of Huelva, Spain', AWE 16, 1-61

Gosden, C. and Marshall, Y. (1999) 'The Cultural Biography of Objects', WorldArch 31.2, $169-78$

Gracia, F. (2003) 'Las cerámicas áticas del Palacio-Santuario de Cancho Roano', in S. Celestino (ed.), Cancho Roano VIII. Los materiales arqueológicos I (Mérida) 23-194

Gracia, F. (2005) 'Las cerámicas griegas en el área occidental de la Península Ibérica entre los siglos VI y IV a.C. El conjunto de materiales del palacio-santuario de Cancho Roano (Zalamea de la Serena, Badajoz)', in S. Celestino and F.J. Jiménez (eds), El periodo orientalizante. Actas del III Simposio Internacional de Arqueología de Mérida: Protohistoria del Mediterráneo Occidental (Mérida) 1173-97

Gracia, F. (ed.) (2008) De Iberia a Hispania (Barcelona)

Graells, R. (2008) 'Mistophoroi ilergetes: el ejemplo de las tumbas de caballo de la necrópolis de la Pedrera (Vallfogona de Balaguer-Térmens, Catalunya, España)', JRGZM 55.1, 81-158

Graells, R. (2014) Mistophoroi ex Iberias. Una aproximación al mercenariado hispano a partir de las evidencias arqueológicas (s. VI-IV a.C.) (Venosa)

Graells, R. (2016) 'Las corazas incorruptas y la permanencia en exposición de algunas armas en santuarios (s.VI a.C.-II d.C.)', Ostraka XXV, 53-66

Graells, R. and Lorrio, A.J. (2017) Problemas de cultura material: Broches de cinturón decorados a molde de la Península Ibérica (s. VII-VI a.C.) (Alicante)

Graells, R., Longo, F. and Zuchtriegel, G. (2017) Le armi di Athena. Il santuario settentrionale di Paestum (Naples)

Grau, I., Olmos, R. and González-Alcalde, J. (2005) 'El ánfora ática de la Cova dels Pilars (Agres, Alicante): una propuesta de lectura iconográfica en su contexto espacial ibérico. Con un apéndice de Julio González-Alcalde, La Cova dels Pilars en el contexto de las cuevas-santuario ibéricas', ArchEspArq 78.191-92, 49-77

Grethlein, J. (2008) 'Memory and material objects in the Iliad and the Odyssey', JHS 128, $27-51$

Guggisberg, M. (2004) 'Keimēlia. Altstücke in fürstlichen Gräbern diesseits und jenseits der Alpen', in M. Guggisberg (ed.), Die Hydria von Grächwil. Zur Funktion und Rezeption mediterraner Importe in Mitteleuropa im 6. und 5. Jahrhundert v. Chr. Akten Internationales Kolloquium Bern 12-13, Oktober 2001 (Bern) 175-92

Halbwachs, M. and Coser, L.A. (1992) On Collective Memory (Chicago and London)

Hamilakis, Y. (2013) Archaeology and the Senses: Human Experience, Memory and Affect (Cambridge)

Hamilakis, Y. (2015) 'Sensuous memory, materiality and history: rethinking the 'rise of the palaces' on Bronze Age Crete', in A.B. Knapp and P. van Dommelen (eds), Materiality, Memory and Identity (Cambridge) 320-36

Hemelrijk, J.M. (1986) 'Plakken, lappen en verlakken', Vereniging Vrienden Allard Pierson Museum Amsterdam 36, 1-14 
Hodder, I. (2012) Entlangled: An Archaeology of the Relationships Between Humans and Things (Oxford)

Hoskins, J. (2006) 'Agency, biography and objects', in C. Tilley, W. Keane, S. Küchler, M. Rowlands and P. Spyer (eds), Handbook of Material Culture (London) 74-84

Izquierdo, I. (2007) 'Arqueología de la muerte y el estudio de la sociedad: Una visión desde el género en la Cultura Ibérica', Complutum 18, 247-61

Jiménez, A. (2006) 'Contextos funerarios en la transición del mundo prerromano al romano en el sur peninsular', in D. Vaquerizo, J. Garriguet and A. León (eds), Espacio y usos funerarios en la ciudad histórica (Córdoba) 67-98

Jiménez, A. (2008) Imagines Hibridae. Una aproximación postcolonialista al estudio de las necrópolis de la Bética (Madrid)

Jiménez, F. J. (2002) La toréutica orientalizante en la Península Ibérica (Madrid)

Kistler, E., Öhlinger, B., Dauth, T., Irovec, R. and Wimmer, B. (2017) 'Archaika as resource. The production of locality and colonial empowerment on Monte Iato (Western Sicily) around 500 BC', in A.K. Scholz, M. Bartelheim, R. Hardenberg and J. Staecker (eds), ResourceCultures. Sociocultural Dynamics and the Use of Resources - Theories, Methods, Perspectives (Tübingen) 159-75

Knight, M., Boughton, D. and Wilkinson, R.E. (eds) (2019) Objects of the Past in the Past: Investigating the Significance of Earlier Artefacts in Later Contexts (Oxford)

Kopytoff, I. (1986) 'The cultural biography of things: commoditization as process', in A. Appadurai (ed.), The Social Life of Things. Commodities in Cultural Perspective (Cambridge) 61-91

Kousser, R. (2009) 'Destruction and memory on the Athenian Acropolis', ArtB 91.3, 263-82

Lamboglia, N. (1952) 'Per una classificazione preliminare della ceramica campana', in Actes du ler Congrès international d'Études Ligures (Monaco-Bordighera-Gênes, 10-17 avril 1950) (Bordighera) 136-206

Langdon, S. (2001) 'Beyond the grave: biographies form early Greece', AJA 105.4, 579-606

Langridge-Noti, E. (2013) 'Consuming iconographies', in A. Tsingarida and D. Viviers (eds), Pottery Markets in the Ancient Greek World (8th-1st centuries BC) (Brussels) 61-72

Langridge-Noti, E. (2015) "To market, to market": pottery, the individual and trade in Athens', in K.F. Daly and L.A. Riccardi (eds), Cities Called Athens. Studies Honoring John McK. Camp II (Lanham) 165-95

Lazzarini, M.L. and Zevi, F. (1989) 'Necrocorinthia a Pompei: una idria bronzea per le gare di Argo', Prospettiva 53/56 Scritti in ricordo di Giovanni Previtali vol.1, 33-48

Lillios, K. (1999) 'Objects of memory: the ethnography and archaeology of heirlooms', Journal of Archaeological Method and Theory 6.3, 235-62

Lucas, G. (2004) The Archaeology of Time (London and New York)

Mata, C. (1991) Los Villares (Caudete de las Fuentes, Valencia): origen y evolución de la cultura ibérica (Valencia)

Melchor, J.M., Ferrer, J.J. and Benedito, J. (2010) 'El enterramiento ibérico de la "Cratera de la Grifomaquia” de Orleyl', Millars XXXIII, 39-54

Mengod, A., Mesado, N., Aranegui, C. and Fletcher, D. (1981) Materiales de la necrópolis ibérica de Orleyl (Vall d'Uxó, Castellón) (Valencia)

Miró, M.T. (2006) La ceràmica àtica de figures roges de la ciutat grega d'Emporion (Girona)

Molinos, M., Chapa, T., Pereira, J., Rísquez, C., Madrigal, A., Esteban, A., Mayoral, V. and Llorente, M. (1998) El santuario heróico de "El Pajarillo” (Huelma, Jaén) (Jaén) 
Moore, M.B. (1997) Attic Red-Figured and White-Ground Pottery, The Athenian Agora (Princeton).

Moratalla, J. and Verdú, E. (2007) 'Pebeteros con forma de cabeza femenina de la Contestania ibérica', in M.C. Marín and F. Horn (eds), Imagen y culto en la Iberia prerromana: los pebeteros en forma de cabeza femenina (Sevilla) 339-66

Morel, J.-P. (1981) Céramique campanienne: les formes (Rome)

Nadalini, G. (2003) 'Considerazioni e confronti sui restauri antichi presenti sulle ceramiche scoperte a Gela', in R. Panvini and F. Giudice (eds), Ta Attika: Veder greco a Gela. Ceramiche attiche figurate dall' antica colonia (Roma) 197-205

Negueruela, I. (1990) Los monumentos escultóricos del Cerrillo Blanco de Porcuna (Jaén) (Madrid)

Nora, P. (ed.) (1984-1992) Les lieux de mémoire. 3 vols. (Paris)

Nora, P. and Kritzman, L.D. (eds) (1996) Realms of Memory: Rethinking the French Past (Paris)

Oliver, A. (2006a) 'La crátera griega de la Punta d'Orleyl en la Vall d'Uixó', Revista Orleyl 3, $39-50$.

Oliver, A. (2006b) El Puig de la Nau, Benicarló (Castellón).

Oliver, A. and Gómez, F. (1989) 'Nuevos enterramientos infantiles ibéricos de inhumación en Castellón', Quaderns de Prehistòria i Arqueologia de Castelló 14, 51-62

Oliver, A. and Gusi, F. (1995) El Puig de la Nau. Un hábitat fortificado ibérico en el ámbito mediterráneo peninsular (Castellón)

Olmos, R. (1990) ‘Orgiastic elements in Iberian iconography?' Kernos 5, 153-71

Olmos, R. (2000-2001) 'Diosas y animales que amamantan: la transmisión de la vida en la iconografía ibérica', Zephyrus 53-54, 353-78

Olmos, R. (2003) 'Vaso griego e imagen orientalizante en la Andalucía ibérica: la colisión de dos tradiciones iconográficas (siglos V-IV a.C.)', in F. Giudice and R. Panvivi (eds), Il greco, il barbaro e la ceramica attica: immaginario del diverso, processi di scambio e autorappresentazione degli indigeni (Rome) 219-28

Olmos, R. (2004) 'La Dama de Galera (Granada): la apropiación sacerdotal de un modelo divino', in J. Pereira, T. Chapa Brunet, A. Madrigal, A. Uriarte and V. Mayoral (eds), La necrópolis ibérica de Galera (Granada). La colección del Museo Arqueológico Nacional (Madrid) 213-38

Olmos, R. (2005) 'Memoria histórica y tradición orientalizante en la iconografía ibérica', in S. Celestino and F.J. Jiménez (eds), El periodo orientalizante. Actas del III Simposio internacional de arqueología de Mérida: Protohistoria del Mediterráneo Occidental (Mérida) 1063-75

Olmos, R. (2010) 'La ninfa Ilike', in T. Tortosa and S. Celestino (eds), Debate en torno a la religiosidad protohistórica (Madrid) 49-64

Olmos, R., Rueda, C., Ruíz, A., Molinos, M., Gómez, F. and Rísquez, C. (2012) 'Imágenes para un linaje: vida, muerte y memoria ritual en la cámara principesca de Piquía (Arjona, Jaen)', in S. Angiolillo, M. Giuman, and C. Pilo (eds), Meixis. Dinamiche di Stratificazione culturale nella periferia greca e romana. Atti del Convegno Internazionali di Studi 'Il sacro e il profano'(Rome) 89-104

Pace, R., and Verger, S. (2012) 'Les plus anciens objets en bronze dans les santuaires de la Grande-Grèce et de la Sicile: les cas du Timpone Motta en Sybaritide et de Bitalemi à 
Gela', in M. Denoyelle, S. Descamps-Lequime, and S. Verge (eds), Bronzes grecs et romains, recherches récentes. Hommage á Claude Rolley

Pachón, J., Carrasco, J. and Aníbal, C. (2007) 'Realidad imitada, modelo imaginado, o revisión de las tradiciones orientalizantes en tiempos ibéricos, a traves de la crátera de columnas de Atalayuelas (Fuerte del Rey/Torredelcampo, Jaén)', Antiquitas 18-19, $17-42$

Parras, D.J., Sánchez, A., Tuñón, J.A., Rueda, C., Ramos, N. and García-Reyes, J.F. (2015) 'Sulphur, fats and beeswax in the Iberian rites of the sanctuary of the oppidum of Puente Tablas (Jaén, Spain)', JAS: Reports 4, 510-24

Peña, J.T. (1998) 'Aspects of residuality in the Palatine east pottery assemblage', in F. Guidobaldi, C. Pavolini, P. Pergola and P. Maria Barbini (eds), I materiali residui nello scavo archeologico (Rome) 5-19

Peña, J.T. (2007) Roman Pottery in the Archaeological Record (Cambridge)

Pereira, J. and Madrigal, A. (1994) 'El ritual funerario ibérico en la Alta Andalucía: la necrópolis de los Castellones de Ceal (Jaén)', in J. Mangas and J. Alvar (eds), Homenaje a José María Blázquez (Madrid) vol. II, 381-94

Pereira, J., Chapa Brunet, T., Madrigal, A., Uriarte, A. and Mayoral, V. (2004) La necrópolis ibérica de Galera (Granada). La colección del Museo Arqueológico Nacional (Madrid)

Pfälzner, P. (2017) "Cultural memory and the invisible dead: the role of "old objects" in burial contexts', in J. Badbury and C. Scarre (eds), Engaging with the Dead: Exploring Changing Human Beliefs about Death, Mortality and the Human Body (Oxford and Philadelphia) 149-62

Pfisterer-Haas, S. (1998) Wenn der Topf aber nun ein Loch hat... Restaurierung griechischer Keramik in Antike und Neuzeit (Leipzig)

Pfisterer-Haas, S. (2002) 'Antike Reparaturen', in M. Bentz (ed.), Vasenforschung und Corpus Vasorum Antiquorum - Standortbestimmung und Perspektiven (Munich) 5159

Reiterman, A.S. (2014) 'Keimēlia in context: towards an understanding of antiquities in the past', in J. Ker and C. Pieper (eds), Valuing the Past in the Greco-Roman World: Proceedings from the Penn-Leiden Colloquia on Ancient Values VII (Leiden) 146-72

Reiterman, A.S. (2016) Keimèlia: Objects Curated in the Ancient Mediterranean (8th-5th Centuries BC) (Ph.D. diss Pennsylvania)

Rodríguez, D. (2019) 'La vida social de la cerámica ática en la Península Ibérica: la amortización de las copas Cástulo de tipo antiguo', ArchEspArq 92, 71-88

Rodríguez, D. and Sánchez. C. 2017. 'La tumba de L'Orleyl. La elección de un ajuar ático', in X. Aquilué, P. Cabrera and M. Orfila (eds), Homenaje a Gloria Trias Rubiés. Cerámicas griegas de la Península Ibérica: cincuenta años después (1967-2017) (Girona) 308-17

Rodríguez, M.O. (2014) La necrópolis ibérica de Tútugi (2000-2012) (Jaén)

Rodríguez, M.O. and Pérez, M. (2013) 'El túmulo 20: un espacio sagrado en la necrópolis ibérica de Tútugi', in C. Rísquez and C. Rueda (eds), Santuarios íberos: territorio, ritualidad y memoria. Actas del congreso El santuario de la Cueva de La Lobera de Castellar 1912-2012 (Jaén)

Rodríguez, M.O., Gómez, F. and Montes, E. (2008) 'El túmulo 20 de la necrópolis ibérica de Tútugi (Galera, Granada)', Trabajos de prehistoria 65.1, 169-80 
Rotroff, S.I. (2011) 'Mended in Antiquity: repairs to ceramics at the Athenian Agora', in M.L. Lawall and J. Lund (eds), Pottery in the Archaeological Record: Greece and Beyond. Acts of the International Colloquium Held at the Danish and Canadian Institutes in Athens (Aarhus) 117-34

Rouillard, P. (1975) 'Coupes attiques à figures du IV s. en Andalousie', Mélanges de la Casa de Velázquez 11.1, 21-49

Rouillard, P. (1991) Les Grecs et la péninsule Ibérique du VIIIe au IVe siècle avant JésusChrist (Paris)

Rouillard, P. (2009) 'Le vase grec entre statut et fonction: le cas de la péninsule Ibérique', in A. Tsingarida (ed.), Shapes and Uses of Greek Vases (7th-4th centuries B.C.) (Brussels) 365-76

Rouillard, P. (2010) 'La cerámica griega en la necrópolis de Cabezo Lucero', in L. Abad (ed.), Guardamar del Segura. Arqueología y museo (Alicante) 114-21

Rous, S.A. (2019) Reset in Stone. Memory and Reuse in Ancient Athens (Winsconsin)

Rueda, C. and Olmos, R. (2016) 'Las cráteras áticas de la Cámara Principesca de Piquía (Arjona): los vasos de la memoria de uno de los últimos linajes iberos', in A. Ruiz and M. Molinos (eds), Jaén, tierra ibera. 40 años de investigación y transferencia (Jaén) 375-92.

Ruiz, A. and Molinos, M. (1993) Los iberos: análisis arqueológico de un proceso histórico (Barcelona)

Ruiz, A. and Molinos, M. (1998) The Archaeology of the Iberians (Cambridge).

Ruiz, A. and Molinos, M. (2015) 'El conjunto escultórico de Cerrillo Blanco, Porcuna', in A. Ruiz and M. Molinos (eds), Jaén, tierra ibera. 40 años de investigación $y$ transferencia (Jaén) 67-84

Ruiz, A. and Molinos, M. (eds) (2015) Jaén, tierra ibera. 40 años de investigación y transferencia (Jaén)

Ruiz, A., Molinos, M., Fernández, R., Pérez, M. and Rueda, C. (2015) 'El santuario de la Puerta del Sol', in A. Ruiz and M. Molinos (eds), Jaén, tierra ibera. 40 Años de investigación y transferencia (Jaén) 93-106

Ruiz, A., Molinos, M., Rísquez, C., Gómez, F. and Lechuga, M.A. (2016) 'La cámara de Piquía, Arjona', in A. Ruiz and M. Molinos (eds), Jaén, tierra ibera. 40 Años de investigación y transferencia (Jaén) 357-74

Ruiz, A., Risquez, C. and Hornos, F. (1992) 'Las necrópolis ibéricas en la Alta Andalucía', in J. Blánquez and V. Antona (eds), Congreso de Arqueología Ibérica: las necrópolis (Madrid) 397-430

Sala-Sellés, F. and Verdú, E. (2014) 'Pebeteros en forma de cabeza femenina en la Contestania. Estado de la cuestión y perspectivas de estudio', in M.C. Marín and A.M. Jiménez (eds), Imagen y culto en la Iberia prerromana II: los pebeteros en forma de cabeza femenina (Sevilla) 19-34

Sánchez, C. (1992) 'Las copas tipo Cástulo en la Peninsula Ibérica', Trabajos de prehistoria $49,327-33$

Sánchez, C. (2012) 'La cerámica griega en Iberia. Las vajillas de mesa y de representación', in X. Aquilué and P. Cabrera (eds), El legado arqueológico griego en la península Ibérica (Girona) 58-66

Sánchez, C. (2014) 'El pintor de Enomao y los talleres áticos del siglo IV a.C. en la Península Ibérica', in P. Bádenas, P. Cabrera, M. Moreno, A. Ruiz, C. Sánchez and T. Tortosa 
(eds), Homenaje a Ricardo Olmos. Per speculum in aenigmate. Miradas sobre la Antigüedad (Madrid) 269-73

Sánchez, C. (2017a) 'Contexts of use of fourth-century Attic pottery in the Iberian Peninsula', in D. Rodríguez (ed.), Greek Art in Context. Archaeological and Art Historical Perspectives (London and New York) 185-98

Sánchez, C. (2017b) 'Selecting an assemblage for the dead: Attic pottery of two rich burials in Baza (Granada)', Ancient West and East 16, 97-111

Sánchez, E. and Gómez, J.L. (eds) (2008) Protohistoria y Antigüedad de la Península Ibérica. Vol. II. La Iberia prerromana y la Romanidad (Madrid)

Sanmartí-Grego, E. (1976) 'Cerámicas de importación ática de El Puig de Benicarló (Castellón)', Cuadernos de Prehistoria y Arqueología Castelloneneses 3, 219-28

Sanmartí-Grego, E. and Gusi, F. (1976) 'Un kylix del pintor de Penthesilea procedente del poblado Ilercavón de El Puig (Benicarló, Castellón)', Cuadernos de Prehistoria y Arqueología Castelloneneses 3, 205-18

Sanmartí, J. (2009) 'Colonial relations and social change in Iberia (seventh to third centuries BC)', in M. Dietler and C. López (eds), Colonial Encounters in Ancient Iberia (Chicago and London) 49-91

Schöne-Denkinger, A. (2007) 'Reparaturen, antik oder nicht antik? Beobachtungen an rotfigurigen Krateren der Berliner Antikensammlung und Anmerkungen zur Verwendung geflickter Gefässe in der Antike', in P. Zanker (ed.), Konservieren oder Restaurieren. Die Restaurierung griechischer Vasen von der Antike bis heute (Munich) 21-28

Shefton, B.B. (1982) 'Discusión a M. Pellicer: Las cerámicas del mundo fenicio en el Bajo Guadalquivir', Phönizer im Western. Madrider Beiträge 8, 403-5

Shefton, B.B. (1986) 'Discusión a los materiales del Pecio del Sec. En Grecs et Ibères au IVe siècle avant Jésus-Christ (Table Ronde Bordeaux 1986)', RÉA LXXXIX, 134-38.

Shefton, B.B. (1990a) 'The Castulo cup: an Attic shape in black glaze of special significance in Sicily (with philological addenda by J.H.W. Penney)', in G. Rizza and F. Giudice (eds), I vasi attici ed altre ceramiche coeve in Sicilia (Catania) 85-98

Shefton, B.B. (1990b) 'Castulo cups in the Aegean, the Black Sea area and the Near East with the respective hinterland', in O. Lordkipanidze and P. Lévêque (eds), Sur les traces des Argonautes. Proceedings of the 6th International Symposium on the Ancient History of the Black Sea Littoral. Vani, Georgia (Besançon, Paris and Tbilisi) 163-86

Shefton, B.B. (1995) 'Greek imports at the extremitites of the Mediterranean, west and east: reflections on the case of Iberia in the fifth century BC', Proceedings of the British Academy 86, 127-55

Sioumpara, E. (2016) 'Recycling the past, second-hand architecture or waste management? Reuse of building materials at the Athenian Acropolis', Paper read at the conference New Approaches and Paradigms in the Study of Greek Architecture, 3-5 November (Athens)

Sioumpara, E. (2018) 'Destruction and construction of order. Reuse of building-materials at Attic sanctuaries after the Persian Wars', Paper read at the conference UMGEBAUT. Umbau-, Umnutzungs-, und Unwertungsprozesse in der antiken Architektur, 21-24 February (Berlin) 
Sparkes, B.A. (2016) 'Some early Attic red-figure stemless cups', in J. Boardman, A. Parkin and S. Waite (eds), On the Fascination of Objects. Greek and Etruscan Art in the Shefton Collection (Oxford and Philadelphia) 83-93

Sparkes, B.A. and Talcott, L. (1970) Black and Plain Pottery of the 6th, 5th and 4th Centuries B.C. Part 1: Text (Athens)

Stamatopoulou, M. (2016) 'Forging a link with the past. The evidence from Thessalian cemeteries in the Archaic and Classical periods', in O. Herny and U. Kelp (eds), Tumulus as Sema. Space, Politics, Culture and Religion in the First Millennium (Berlin) 181-204

Stockhammer, P.W. and Fries-Knoblach, J. (eds) (2019) In die Töpfe geschaut. Biochemische und kulturgeschichtliche Studien zum früheisenzeitlichen Essen und Trinken (Leiden).

Stockhammer, P.W. and Fries-Knoblach, J. (eds) (2019) Was tranken die fruhen Kelten? Bedeutungen und Funktionen mediterraner Importe im fruheisenzeitlichen Mitteleuropa. International Konferenz Kloster Weltenburgh 28.04.-01.05.2017 BEFIM 1 (Leiden)

Thomas, N. (1991) Entangled Objects: Exchange, Material Culture and Colonialism in the Pacific (Cambridge, Mass.)

Trías, G. (1967) Cerámicas griegas de la Península Ibérica (Valencia)

Tsingarida, A. (2009) 'Vases for heroes and gods: early red-figure Parade Cups and largescaled phialai', in A. Tsingarida (ed.), Shapes and Uses of Greek Vases (7th-4th centuries B.C.) (Brussels) 185-203

Valenciano, M.C. (2000) El Llano de la Consolación (Montealegre del Castillo, Albacete). Revisión crítica de una necrópolis ibérica del Sureste de la Meseta (Albacete)

Van Dyke, R.M. (2019) 'Archaeology and social memory', Annual Review of Anthropology $48,207-25$

Van Dyke, R.M. and Alcock, S.E. (eds) (2003) Archaeologies of Memory (Maiden)

Van Gijn, A., Fries-Knoblach, J. and Stockhammer, P.W. (eds) (forthcoming) Pots and Practices. An Experimental and Microwear Approach to Early Iron Age Vessel Biographies

Verdú, E. (2014) La necrópolis ibérica de L'Albufereta. Ritos y usos funerarios en un contexto de interacción cultural (Ph.D. diss. Alicante)

Verdú, E. (2015) La necrópolis ibérica de L'Albufereta (Alacant). Ritos y usos funerarios en un contexto de interacción cultural (Alicante)

Verger, S. (2019a) 'Les incroyables tribulations d'un anneau de jambe auvergnat de l'âge du fer: circulation, stockage, conservation et utilisation des lots de fragments d'objets de brone en Méditerranée occidentale aux VII-VI siècles avant J.-C.', Dialogues d'histoire ancienne 45.1, 244-90

Verger, S. (2019b) 'Manipulation des objets et recomposition du passé dans les sociétés de l'âge du fer', in R. Golosetti (ed.), Mémoire de l'âge du fer. Effacer ou réécrire le passé (Paris) 237-86

Vives-Ferrándiz, J. (2005) Negociando encuentros. Situaciones coloniales e intercambios en la costa oriental de la Península Ibérica (ss. VIII-VI a.C.) (Barcelona)

Vives-Ferrándiz, J. (2010) 'Mobility, materiality and mediterranean identities in Iron Age east Iberia: on the approrpiation of material culture and the question of judgement', in P. van Dommelen and A.B. Knapp (eds), Material Connections in the Ancient 
Mediterraenan: Mobility, Materiality and Mediterranean Identities (London) 190209

Walsh, J. (2014) Consumerism in the Ancient World (New York and London)

Walsh, J. (2019) 'Contextualizing Greek pottery at Hallstatt sites', in P.W. Stockhammer and J. Fries-Knoblach (eds), Was tranken die Frühen Kelten? Bedeutungen und Funktionen mediterraner Importe im früheisenzeitlichen Mitteleuropa. Internationale Konferenz, Kloster Weltenburgh, 28.04.-01-05.2017 (Leipzig) 287-98

Whitley, J. (1994) 'The monuments that stood before Marathon: tomb cult and hero cult in Archaic Attica', AJA 98.2, 213-30

Whitley, J. (2013) 'Homer's entangled objects: narrative, agency and personhood in and out of Iron Age texts', $C A J$ 23.3, 395-416

Williams, H. (2013) 'Death, memory and material culture: catalytic commemoration and the cremated dead', in L.N.Stutz and S. Tarlow (eds), The Oxford Handbook of the Archaeology of Death and Burial (Oxford) 195-208

Zerubavel, E. (2003) Time Maps. Collective Memory and the Social Shape of the Past (Chicago)

Figure captions

Figure 1.- Polychrome Iberian urn from tomb 155 of Baza (Granada). Madrid, Museo Arqueológico Nacional inv. no. 1969/68/155/9 (photograph courtesy of the Museo Arqueológico de Madrid).

Figure 2.- Main sites mentioned in the text (by the author)

1.- Ampurias (Gerona); 2.- Ullastret (Gerona); 3.- Puig de la Nau (Benicarló, Castellón); 4.- L’Orleyl (La Vall d’Uixó, Castellón); 5.- Puntal dels Llops (Olocau, Valencia); 6.- Castellet de Bernabé (Líria, Valencia); 7.- Edeta - Tossal de San Miguel (Líria, Valencia); 8.- Los Villares (Caudete de las Fuentes, Valencia); 9.- La Albufereta and Tossal de les Basses (Alicante); 10.- Cabezo Lucero (Guardamar del Segura, Alicante); 11.- Coimbra del Barranco Ancho (Jumilla, Murcia); 12.- El Cabecico del Tesoro (Verdolay, Murcia); 13.- Galera (Huéscar, Granada); 14.- Baza (Baza, Granada); 15.- Castellones de Ceal (Hinojares, Jaén); 16.- Piquía (Arjona, Jaén); 17.- Cerrillo Blanco (Porcuna, Jaén); 18.- Puente Tablas (Jaén); 19.- Cerrillo de la Compañía de Hornos (Hornos de Peal, Jaén); 20.- La Quéjola (San Pedro, Albacete); 21.- El Llano de la Consolación (Montealegre del Castillo, Albacete); 22.Pozo Moro (Chinchilla de Montearagón, Albacete)

Figure 3.- Alabaster statuette known as the "Lady of Galera". From tomb 20 of the necropolis of Galera (Granada). Madrid, Museo Arqueológico Nacional inv. no. 33438 (photograph by the author).

Figure 4.- Cástulo cup from tomb 20 of the necropolis of Galera (Granada). Madrid, Museo Arqueológico Nacional inv. no. 1979/70/GAL/T20/9 (photograph by the author).

Figure 5.- Red-figure type B cups by the Painter of London E 106 from La Albufereta (Alicante). Alicante, Museo Arqueológico de Alicante, inv. nos. CS3639 and 6063 (photograh courtesy of the Museo Arqueológico de Alicante).

Figure 6.- Four Athenian red-figure bell-kraters from Piquía (Arjona, Jaén). Jaén, Museo de Jaen inv. nos. DJ/DA07083-86. After Rueda and Olmos Romera (2016) 222, fig.11. 
Figure 7.- Athenian red-figure type B cup from El Puig de la Nau (Benicarló, Castellón) attributed to the Penthesilea Painter (photograph courtesy of SIAP. Diputación de Castellón).

Figure 8.- Details of the red-figure type B cup from El Puig de la Nau (Benicarló, Castellón) attributed to the Penthesilea Painter (photograph courtesy of SIAP. Diputación de Castellón).

Figure 9.- Cástulo cup from L’Orleyl (Vall D’Uixó, Castellón). Museo de Buriana (photograph courtesy of the Museo de Burriana)

Figure 10.- Drawing of the grave-goods of the tomb of L'Orleyl (Vall D’Uixó, Castellón). After Cabrera Bonet and Sánchez Fernández 1998, 138, figure 1.

Figure 11.- Cástulo cup from tomb 149 of the necrópolis of Galera (Granada). Madrid, Museo Arqueológico Nacional inv. no. 1979/70/GAL/T149/6 (photograph by the author).

Figure 12.- Athenian red-figure bell-krater from L'Orleyl attributed to the Amazon Painter. Museo de Burriana (photograph courtesy of the Museo de Burriana). 